University of Nebraska - Lincoln DigitalCommons@University of Nebraska - Lincoln

1989

STABLE ISOTOPES IN PRECIPITATION AND GROUND WATER IN THE YUCCA MOUNTAIN REGION, SOUTHERN NEVADA: PALEOCLIMATIC IMPLICATIONS

Larry Benson

University of Colorado at Boulder, great.basin666@gmail.com

Harold Klieforth

Desert Research Institute

Follow this and additional works at: http:/ / digitalcommons.unl.edu/usgsstaffpub

Benson, Larry and Klieforth, Harold, "STABLE ISOTOPES IN PRECIPITATION AND GROUND WATER IN THE YUCCA MOUNTAIN REGION, SOUTHERN NEVADA: PALEOCLIMATIC IMPLICATIONS" (1989). USGS Staff-- Published Research. 789.

http://digitalcommons.unl.edu/usgsstaffpub/789

This Article is brought to you for free and open access by the US Geological Survey at DigitalCommons@University of Nebraska - Lincoln. It has been accepted for inclusion in USGS Staff -- Published Research by an authorized administrator of DigitalCommons@University of Nebraska - Lincoln. 
Geophysical Monograph 55

\title{
STABLE ISOTOPES IN PRECIPITATION AND GROUND WATER IN THE YUCCA MOUNTAIN REGION, SOUTHERN NEVADA: PALEOCLIMATIC IMPLICATIONS
}

\author{
Larry Benson \\ Interdisciplinary Climate Systems Group \\ Room 135, National Center of Atmospheric Research, Boulder, CO 80307
}

Harold Klieforth

Atmospheric Sciences Center

Desert Research Institute, Reno, NV 89506

\begin{abstract}
Unadjusted ages of ground-water samples indicate that most recharge in the Yucca Mountain and Amargosa Desert areas of southern Nevada may have occurred between 18,500 and 9000 years before present. Comparison of the stable-isotope $\left(\delta^{18} \mathrm{O}-\delta \mathrm{D}\right)$ concentrations in this water with stable-isotope concentrations in precipitation in the southern Nevada area indicates that ground-water recharge occurred by infiltration of coldseason precipitation. Infiltration of snowmelt along the bottom of Fortymile Canyon seems to be the most likely recharge mechanism for Yucca Mountain ground water. Ground-water recharge in southern Nevada was nearly synchronous with the last lake cycle in the Lahontan basin in northern Nevada. This regional-scale change in the hydrologic balance occurred during the transition from maxımum-glacial to interglacial conditions and was associated with a change in the location of the air-parcel moisture-source region in the eastern Pacific Ocean and with a warming of the climate between 18,500 and 9000 years before present. In the study area the temperature of condensation of precipitation that infiltrated to the water table increased by about $5{ }^{\circ} \mathrm{C}$. The warming trend also contributed to the recession of mountain glaciers in northern Nevada. Recent atmospheric global climate model simulations provide an integrating theory that accounts for the near synchroneity of ice sheet, lake, and ground-water cycles. In the model the position and persistence of the jetstream, which is associated with the progression of maximum effective precipitation, is substantially affected by the size and shape of the continental ice sheet.
\end{abstract}

\section{Introduction}

In a recent paper Benson and Thompson [1987a] suggested that the timing of the last highstand lake in the Lahontan basin was associated with change in the mean position of the jetstream during the Late Wisconsin. Recent atmospheric global climate model (AGCM) results [Kutzbach and Wright, 1985; Manabe and Broccoli, 1985; Kutzbach and Guetter, 1986; Kutzbach, 1987; and Rind, 1987] support this concept. These studies have shown that between 18,000 and 15,000 years before present (yr B.P.) significant changes occurred in the glacial age circulation at both the surface and jetstream levels that primarily were the result of glacial age lower boundary conditions (ice-sheet size, sea level, sea-ice extent, sea-surface temperature, and land albedo). This widespread change indicates the possibility that the

This paper is not subject to U.S. copyright. Published in 1989 by the American Geophysical Union. record of lake-level change in the Lahontan basin was principally a function of the size and extent of the continental ice sheet. When the ice sheet was large (Figure 1), the polar-front jetstream was forced over the southwestern United States and provided sufficient effective moisture, in terms of increased precipitation and cloudiness, for the formation of highstand lakes [Benson and Thompson, 1987a,b; Lao and Benson, 1988].

Benson and Thompson [1987b] observed that the maximum extent of Late Wisconsin glacation in the northern part of the Great Basin preceded the highest stand of Lake Lahontan [Dom et al., 1987]. This indicates increased moisture availability at a time when glaciers in the upper reaches of water sheds were retreating. To explain this observation Benson and Thompson [1987a] hypothesized that the seasonality of precipitation shifted to warmer

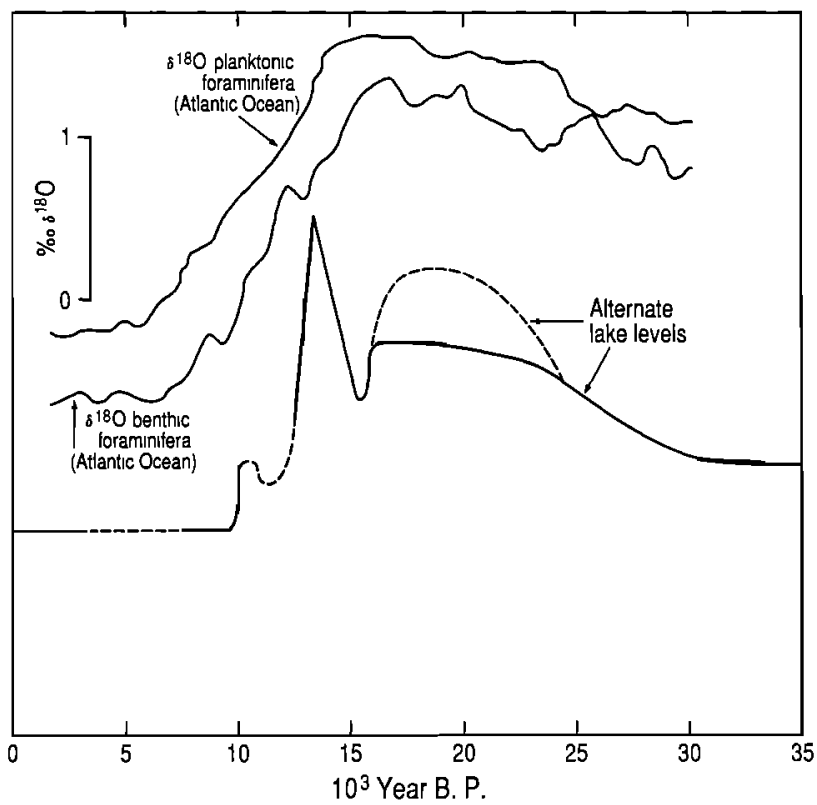

Fig. 1. Graph comparing the Lahontan lake-level record and the $\delta^{18} \mathrm{O}$ records for Atlantic Ocean planktonic and benthic Foraminifera (see text for data sources). 
months or, alternatively, winters became warmer. It is also possible that the climate became generally warmer, but evaporation over lake basins was reduced by persistent cloud cover.

This paper addresses the question: What type of climatic change occurred in the Great Basin between 18,500 and $9000 \mathrm{yr}$ B.P.? It does so by examıning the Great Basin Late-Wisconsin climatic and hydrologic change (lake level, ground water and glacial cycles) in terms of the isotope ( $\delta \mathrm{D}$ and $\delta^{18} \mathrm{O}$ ) concentrations in ground water recharged in the Yucca Mountain area of southern Nevada since about $18,500 \mathrm{yr}$ B.P. (Figure 2). Yucca Mountain, which lies about $350 \mathrm{~km}$ south of the geographic center of Lake Lahontan, is the nearest area where a reasonable amount of data exist on the timing and isotopic chemistry of ground-water recharge during the Late Wisconsin. The climatic conditions existing during recharge were inferred using the light-isotopic concentration of present-day precipitation known as a function of four interrelated variables (season, air temperature, airparcel trajectory and altitude).

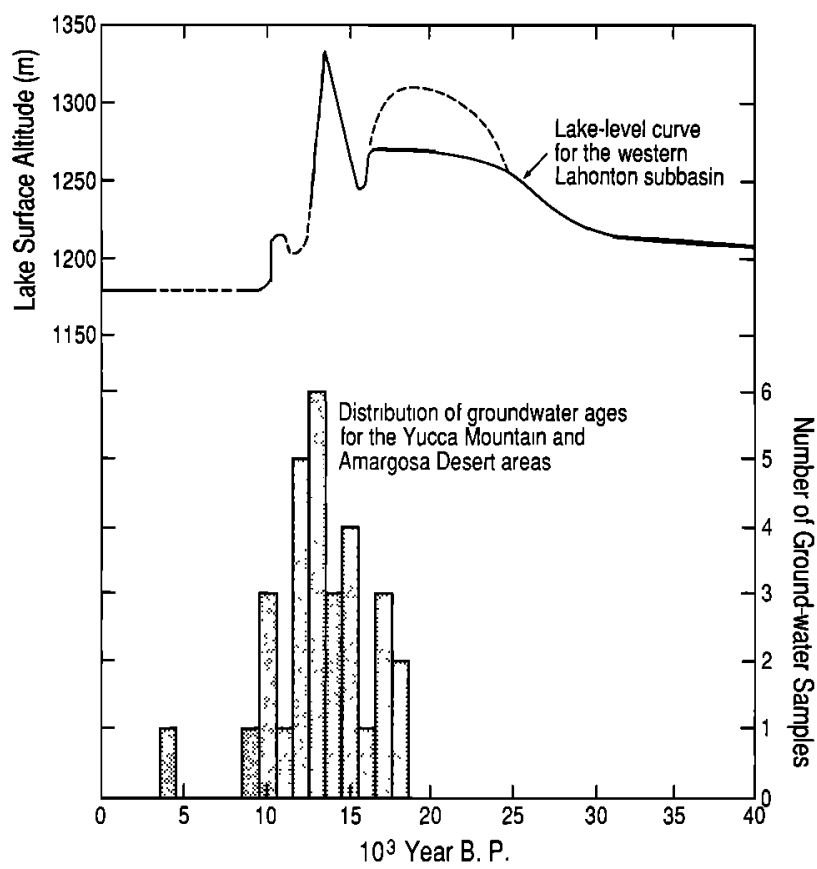

Fig. 2. Graph comparing the Lahontan lake-level record with the distribution of unadjusted ground-water ages in the Yucca Mountain and Amargosa Desert areas.

\section{Methods}

Ground water from several wells located on or near Yucca Mountain, Nevada, (Figure 3) were sampled and analyzed from 1971 to 1984 by members of the U.S. Geological Survey. Drilling, sampling and analytical procedures are those described in Benson et al. [1983]. The isotopic composition and unadjusted radiocarbon ages of the water samples are listed in Table $1 \mathrm{a}$ and $1 \mathrm{~b}$ [Benson and McKinley, 1985].

Age adjustment of three ground-water samples (J-12, J-13, UE29-a \# 2) have been attempted previously [White and Chuma, 1987] using the EQ3NR/EQ6 software package [Wolery 1979, 1985]. Corrected ${ }^{14} \mathrm{C}$ ages of each of the ground-water samples were about 2000 years less than unadjusted ages. Studies of the chemical composition of recent floodwater that occurred in the Fortymile Wash area near Yucca Mountain (Benson et al., in preparation) indicate that the munus 2000-year correction factor represents

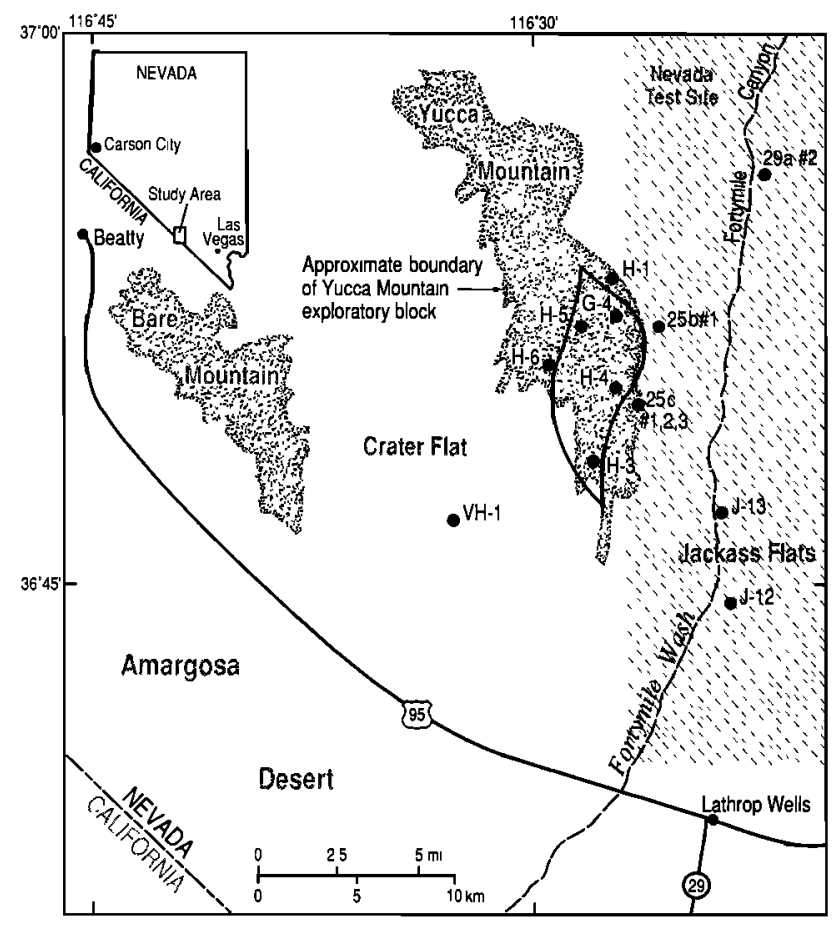

Fig. 3. Map showing location of selected test wells in the Yucca Mountain area.

a maxımum value. In their calculations White and Chuma [1987] used pure water to represent the composition of recharge water and allowed calcium carbonate (containing 100 percent dead carbon) to dissolve until the composition of the simulated ground water was the same as the composition of the actual ground water. The quantity of dead carbon input to the water was then used to correct the ${ }^{14} \mathrm{C}$ age of the sample. However, distributionof-species and saturation-state calculations using EQ3NR indicate that present-day floodwaters (thought to represent the recharge source for J-12, J-13 and UE-29a \# 2 ground water [Claassen, 1985]) in Fortymile Wash are saturated with calcium carbonate and contain 100 percent modern carbon. Input of floodwater chemical compositions to EQ3NR/EQ6 simulations of the composition of Yucca Mountain ground water, therefore, are expected to result in relatively small ${ }^{14} \mathrm{C}$ corrections.

From August 1983 through August 1986, 429 precipitation samples were collected at 12 southern Nevada stations (Figures 4 and 5). The latitude, longitude, and altitude of each station are listed in Table 2. The sampling interval of precipitation samples was halted within 24 hours after the cessation of precipitation in order to isolate individual precipitation events and minimize the effect of evaporation on the isotopic content of the sample. The date and approximate time that precipitation began and ended and the volume and the type of precipitation (rain, snow, or hail) were recorded. In June 1985 Campbell Scientific $21 X$ Microloggers (use of brand, firm, or trade names in this report is for identification purposes only and does not constitute endorsement by the U.S. Geological Survey) were installed at seven precipitation collection stations (Figure 5). Each micrologger was connected to a temperature probe and to a tipping-bucket rain gage. The micrologger recorded Julian date, time, temperature, and rain-gage bucket tips at 15-mınute intervals. Prior to the installation of microloggers, data from two meteorological towers at Yucca Mountain (H.W. Church, Sandia National Laboratory, written comm., 1985) were used to estimate time and temperature of precipitation at five stations (Sandy, Dianne, Marge, Carolyn 


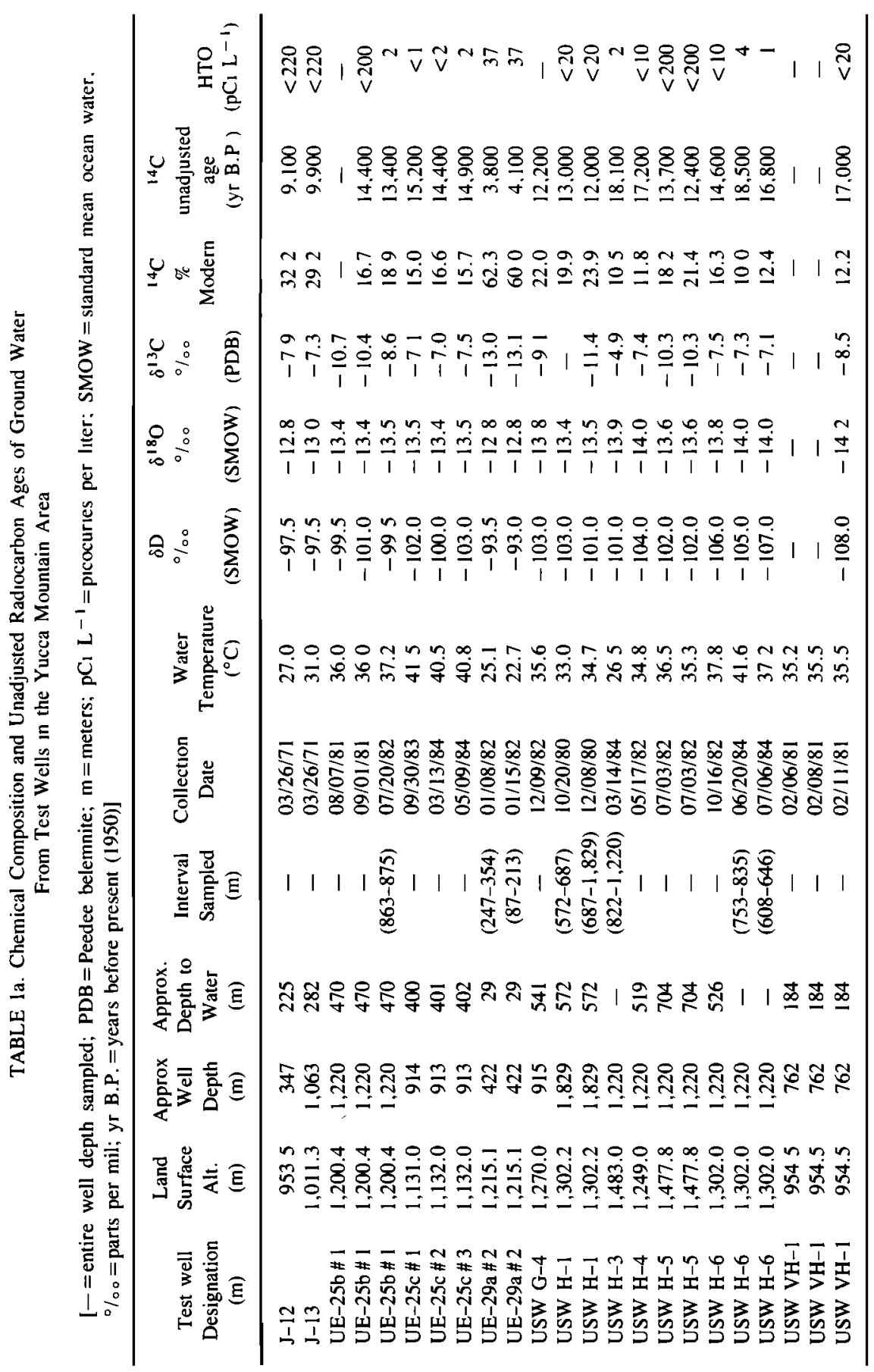




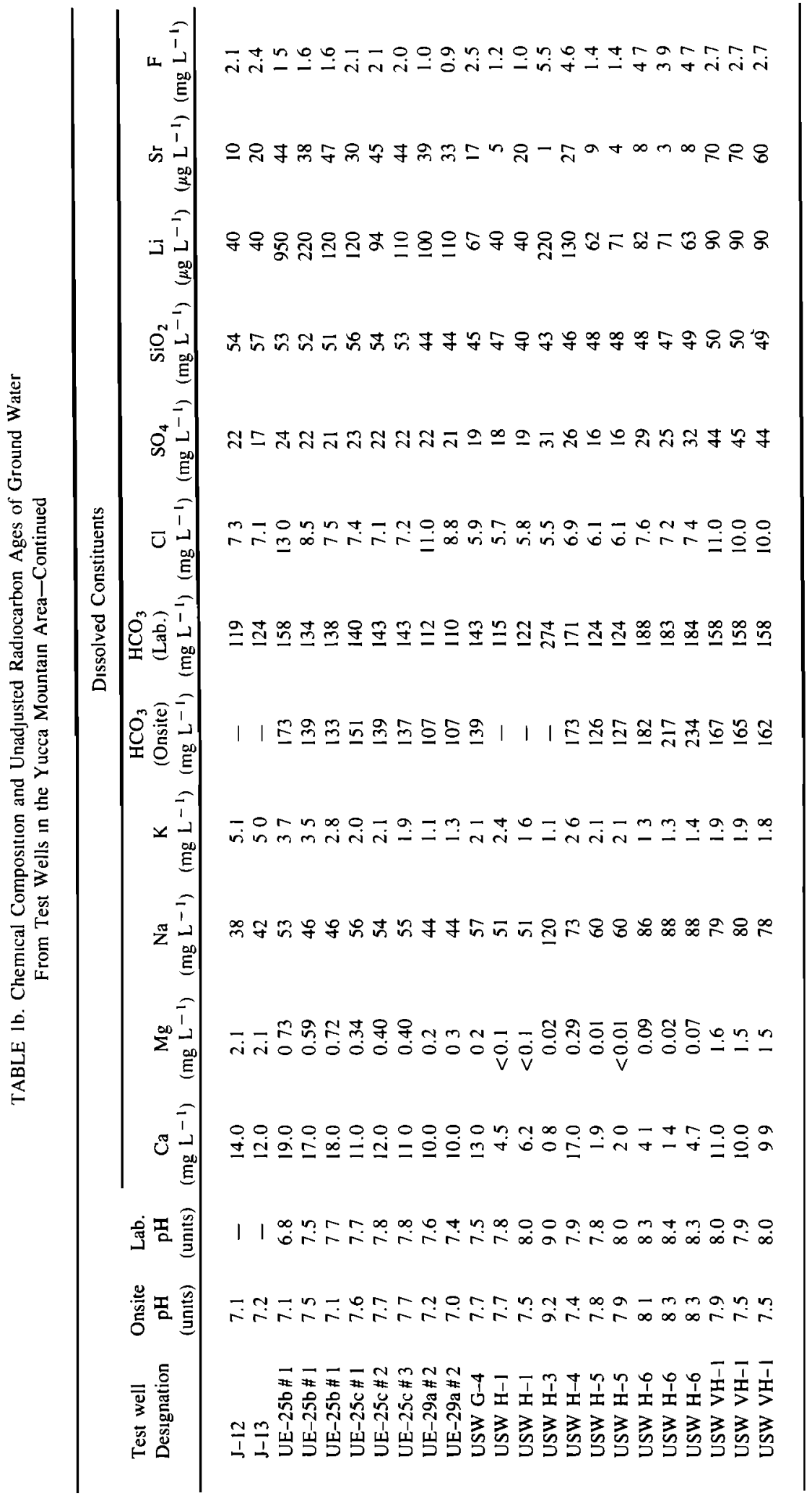




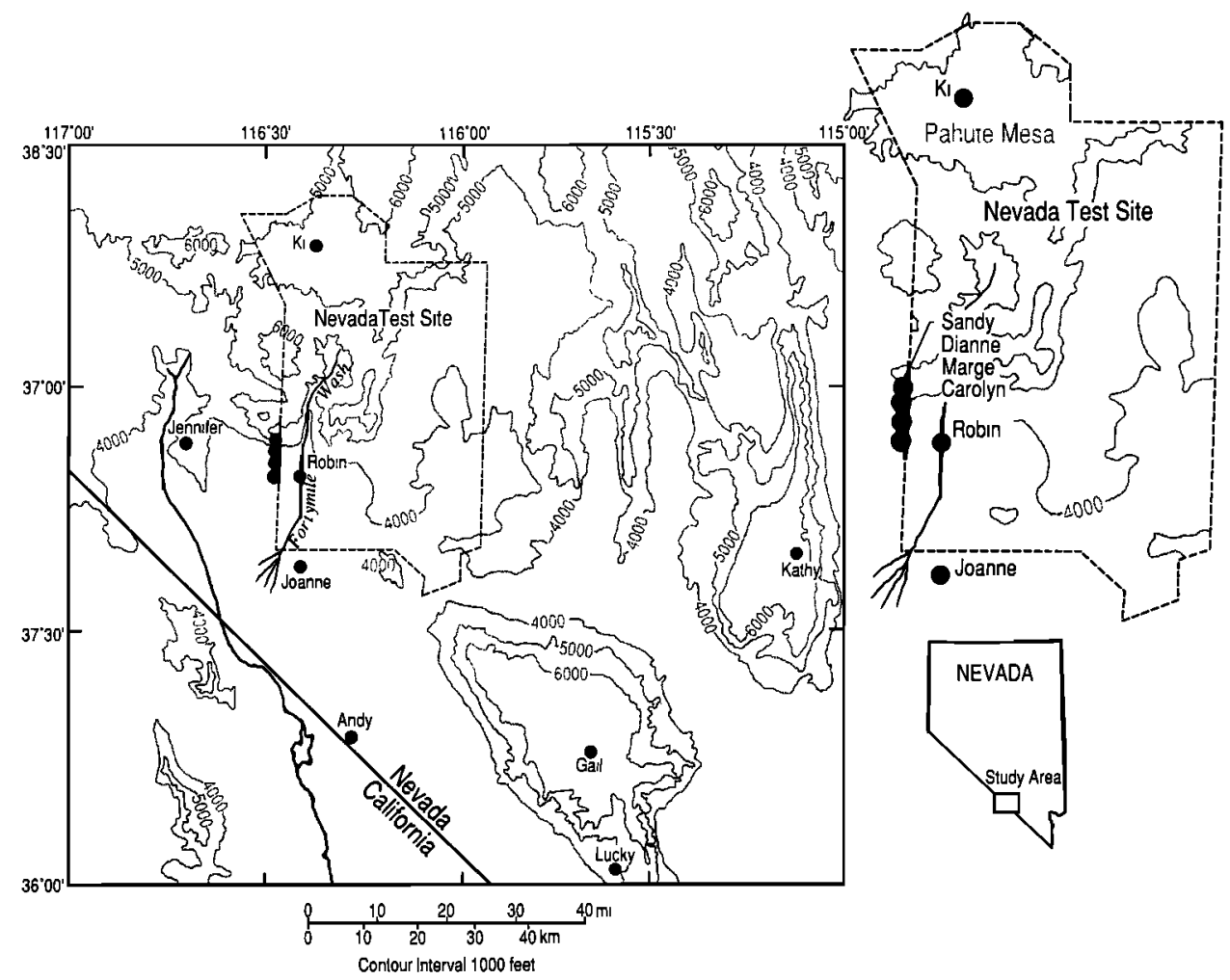

Fig. 4. Map showing location of precipitation-collection stations in southern Nevada.

and Robin). Prior to January 26, 1985, data were not collected for snow depth or equivalent moisture. These data are available for some precipitation samples collected after January 26, 1985. A detailed discussion of onsite and laboratory procedures and a listing of basic data are included in Milne et al. [1987].

The locations of storm moisture sources were estimated for each precipitation episode using synoptic weather charts, precipitation measurements, satellite photographs, and other meteorological observations. The principal

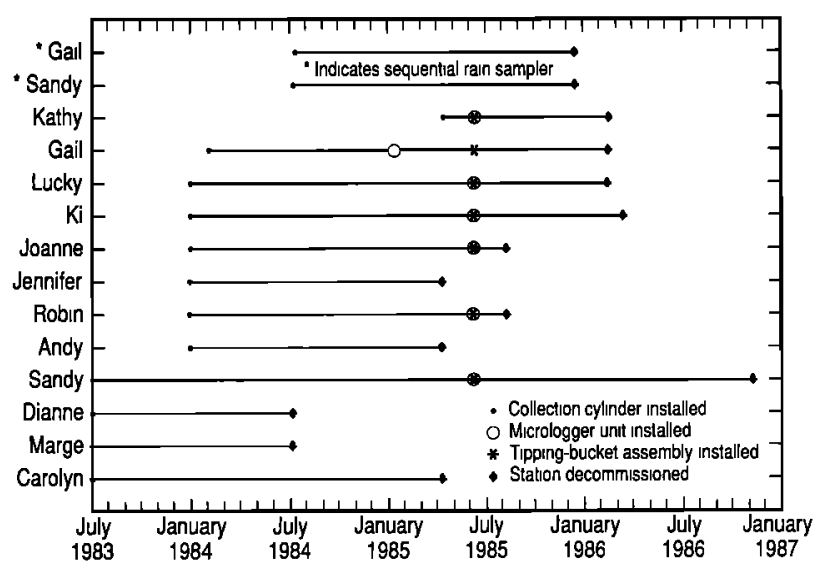

Fig. 5. Graph showing time lines for station installation, equipment installation, and station decommissioning. sources of information were: Daily Weather Maps [NOAA, 1983-1986a]; Climatological Data for California and Nevada [NOAA, 1983-1986b]; Hourly Precipitation Data for Nevada and California [NOAA, 1983-1986c]; Storm Data [NOAA, 1983-1986d]; and Weekly Weather and Crop Bulletins [NOAA, 1983-1986e].

The 500-mb level $(5500-5800 \mathrm{~m})$ was used because it is a representative indicator of tropospheric motion. The airflow in a Pacific storm is complex. While the storm itself may approach from the northwest, the surface

TABLE 2. Location and Altitude of Precipitation-Collection Stations

\begin{tabular}{lllc}
\hline Station name & Latitude & Longitude & $\begin{array}{c}\text { Altitude } \\
\text { (meters) }\end{array}$ \\
\hline Carolyn & $36^{\circ} 49^{\prime} 06^{\prime \prime} \mathrm{N}$. & $116^{\circ} 27^{\prime} 56^{\prime \prime} \mathrm{W}$ & 1,480 \\
Marge & $36^{\circ} 50^{\prime} 13^{\prime \prime} \mathrm{N}$. & $116^{\circ} 27^{\prime} 56^{\prime \prime} \mathrm{W}$. & 1,500 \\
Dianne & $36^{\circ} 51^{\prime} 21^{\prime \prime} \mathrm{N}$ & $116^{\circ} 72^{\prime} 56^{\prime \prime} \mathrm{W}$ & 1.475 \\
Sandy & $36^{\circ} 52^{\prime} 13^{\prime \prime} \mathrm{N}$. & $116^{\circ} 27^{\prime} 56^{\prime \prime} \mathrm{W}$. & 1,480 \\
& & & \\
Andy & $36^{\circ} 16^{\prime} 05^{\prime \prime} \mathrm{N}$. & $116^{\circ} 10^{\prime} 28^{\prime \prime} \mathrm{W}$ & 760 \\
Robın & $36^{\circ} 48^{\prime} 55^{\prime \prime} \mathrm{N}$. & $116^{\circ} 23^{\prime} 42^{\prime \prime} \mathrm{W}$. & 1,020 \\
Jennifer & $36^{\circ} 53^{\prime} 00^{\prime \prime} \mathrm{N}$. & $116^{\circ} 40^{\prime} 24^{\prime \prime} \mathrm{W}$. & 1,425 \\
Joanne & $36^{\circ} 37^{\prime} 59^{\prime \prime} \mathrm{N}$. & $116^{\circ} 20^{\prime} 34^{\prime \prime} \mathrm{W}$. & 855 \\
& & & \\
Ki & $37^{\circ} 16^{\prime} 05^{\prime \prime} \mathrm{N}$. & $116^{\circ} 29^{\prime} 00^{\prime \prime} \mathrm{W}$. & 2,145 \\
Lucky & $36^{\circ} 01^{\prime} 05^{\prime \prime} \mathrm{N}$. & $115^{\circ} 34^{\prime} 00^{\prime \prime} \mathrm{W}$. & 1,395 \\
Gall & $36^{\circ} 15^{\prime} 44^{\prime \prime} \mathrm{N}$. & $115^{\circ} 36^{\prime} 44^{\prime \prime} \mathrm{W}$ & 2,145 \\
Kathy & $36^{\circ} 40^{\prime} 15^{\prime \prime} \mathrm{N}$. & $115^{\circ} 05^{\prime} 50^{\prime \prime} \mathrm{W}$ & 1,900 \\
\hline
\end{tabular}


flow may be southerly and the clouds and precipitation cells may propagate toward the east. Most storms over the Great Basin extend to the tropopause and, therefore, involve stratospheric air. Major winter storms commonly extend above $9000 \mathrm{~m}$ and summer convective storms often extend above $12,000 \mathrm{~m}$. Therefore the $500-\mathrm{mb}$ flow pattern provides an approxımate trajectory of the mean-horizontal flow of moist air into a storm and is thus an approximate indicator of the moisture source region. In using this method of trajectory analysis it is also recognized that the principal moisture source region for a particular storm is not easy to locate; primarily because it is difficult to determine where along its trajectory the storm took on water.

Results and Discussion

In this section the following questions are addressed:

(1) When did the last cycle of ground-water recharge occur in southern Nevada and was it synchronous with the last lake cycle in northern Nevada?

(2) Did ground-water recharge occur by infiltration of floodwater along the bottom of wash systems or did recharge occur in upland areas?

(3) What was the climate during the last recharge cycle and what type of climate change caused mountain glaciers to recede before the Lake Lahontan achieved its maximum extent?

(4) How do the results of recent AGCM experiments aid in understanding the changes in Great Basin synoptic climate that occurred in the last 18,000 years?

\section{Synchroneity of Lake and Ground Water Recharge Cycles}

The isotopic concentration and unadjusted ${ }^{14} \mathrm{C}$ ages of ground water from volcanic tuffs in the Yucca Mountain area are listed in Table 1a. The unadjusted ages range from about $3800 \mathrm{yr}$ B.P. to about $18,500 \mathrm{yr}$ B.P. Most of the ages are in the 12,000 to $18,500 \mathrm{yr}$ B.P. range (Figure 6). The distribution of Yucca Mountain ground-water ages is similar to the distribution of ages (Table 3) of shallow ground-water samples collected from irrigation wells located 15 to $25 \mathrm{~km}$ south of Yucca Mountain in the Amargosa

Test wells within 1 kilometer of Yucca Mountain (except USW VH-1)

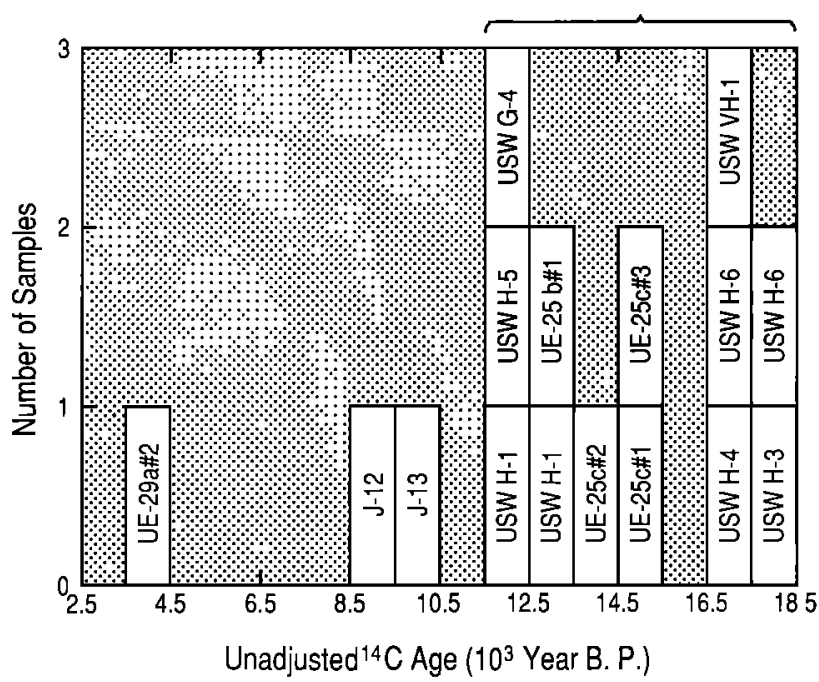

Fig. 6. Graph showing histogram of unadjusted ground-water ages from the Yucca Mountain area.
Desert [Claassen, 1985, and Figure 7]. Carbon-14 data for wells having a probable carbonate lithology were not used. The combined distribution of ground-water ages for the Yucca Mountain and Amargosa Desert areas is simlar to the lake-level records for western subbasins in the Lake Lahontan system (Figure 2). Note that recharge may have continued for a few thousand years after the main recession of Lake Lahontan 13,000 yr B.P. Currey [1988] demonstrated that the final shallow-lake oscillation occured about 11,000 yr B.P. in the Carson Desert subbasin of the Lahontan basin and data for Lake Bonneville [Currey and Oviatt, 1985] indicate the presence of a moderate szed lake in the Bonneville basin at $10,500 \mathrm{yr}$ B.P. In addition, Searles Lake may have overflowed during this time [Smith, 1968].

Adjustment of the ground-water ages to account for acquisition of dead carbon during recharge and transport may further shift the distribution to younger ages (see above), but to a first approximation, the timing of the last major cycle of ground-water recharge in the Yucca Mountain and Amargosa Desert areas seems to be nearly synchronous with the last lake cycle in northern Nevada. Ground-water samples older than 19,000 yr B.P. have not been reported, and only one sample younger than 9000 yr B.P. (well UE-29a \#2, Table 1a) has been reported. Ground-water recharge seems to have started at the time of maximum glaciation and ended during the early stages of deglaciation (compare Figures 1 and 2).

\section{Reliability of Ground Water ${ }^{14} \mathrm{C}$ Ages}

Three processes may have altered the temporal distribution of groundwater ages: (1) mixing of different age ground water, (2) contamination of ground water by the introduction of drilling fluid, and (3) contamination of ground water by exchange of carbon dioxide across the air-water interface. Results of borehole-flow surveys Figures 4-6 in Benson et al. [1983] indicate that fluid production was usually from a few discrete permeable intervals in the fractured volcanic aquifer If water from these intervals contain differing amounts of ${ }^{14} \mathrm{C}$, the pumping process would have produced an integrated or mixed water sample having a ${ }^{14} \mathrm{C}$ concentration in direct proportion to the relative amounts and ${ }^{14} \mathrm{C}$ activities of water from each discrete fracture zone. Samples obtained by pumping isolated intervals in each of three test wells (wells UE-25b \# 1, USW H-1, USW H-6, Table 1a) indicate variability in their ${ }^{14} \mathrm{C}$ ages in excess of that resulting from counting error. This indicates that mixing of ground-water samples having slightly different ${ }^{14} \mathrm{C}$ activities occurred when the entire length of a Yucca Mountain borehole was pumped. The mixing of "old" and "young" ground water results in a ground-water sample having an intermediate age. Therefore a reduction in the variability of the distribution of ground-water ages has occurred but only to a limited extent.

During drilling of the test wells, fluid (usually pumped from well J-13) was introduced into the volcanic aquifer. In order to minimize contamination from the introduction of drilling fluid, wells in the Yucca Mountain area were pumped for 2 to 13 days before water samples were taken for isotopic analysis. To detect the presence of drilling-fluid contamination during pumping, ground water was monitored for temperature, specific conductance, $\mathrm{pH}$, and lithium (after 1982 a known concentration $\left(20 \mathrm{mg} \mathrm{L}^{-1}\right)$ of lithium chloride or lithium bromide tracer was added to the drilling fluid). Lithium was chosen as a tracer because its background concentration in Yucca Mountain ground water is small, approximately $50 \mu \mathrm{g} \mathrm{L}^{-1}$ [Benson et al., 1983].

Samples submitted for ${ }^{14} \mathrm{C}$ determination were also analyzed for tritium $\left({ }^{3} \mathrm{H}\right)$. Only two samples, both from well UE-29a \# 2 , contain ${ }^{3} \mathrm{H}$ in amounts significantly above the level of detection (approximately $2 \mathrm{pCi} \mathrm{L}^{-1}$ in this case). However, the lithium concentration in samples from well UE-29a \#2 is only about twice the background concentration $\left(100-110 \mu \mathrm{g} \mathrm{L}^{-1}\right)$ indicating a very small degree of contamination (approximately 0.2 parts per thousand $(\% \circ)$ ) by drilling fluid (Figure 12 and Appendix in Benson et al. [1983]). 
TABLE 3 Isotopic Composition and Unadjusted Radiocarbon Ages of Selected Ground-Water Samples in the Amargosa Desert [Claassen. 1985] and Pahute Mesa [White and Chuma. 1987] Areas

$\mathrm{IAD}=$ Amargosa Desert. $\mathrm{PM}=$ Pahute Mesa: $\mathrm{m}=$ meters, $\mathrm{SMOW}=$ standard mean ocean water: $\% \circ=$ parts per mul. yr B P. $=$ years before present $(1950),-=\mathrm{No}$ datal

\begin{tabular}{|c|c|c|c|c|c|}
\hline $\begin{array}{c}\text { Well } \\
\text { designation }\end{array}$ & $\begin{array}{l}\text { Approx } \\
\text { well depth } \\
(\mathrm{m})\end{array}$ & $\begin{array}{c}\text { Approx. } \\
\text { depth to } \\
\text { water }(\mathrm{m})\end{array}$ & $\begin{array}{c}\delta \mathrm{D} \\
\% \% \\
\text { (SMOW) }\end{array}$ & $\begin{array}{c}\delta^{18} \mathrm{O} \\
\% \% 0 \\
\text { (SMOW) } \\
\end{array}$ & $\begin{array}{c}{ }^{1+} \mathrm{C} \\
\text { unadjusted } \\
\text { (yr B P ) }\end{array}$ \\
\hline AD-3 & 150 & 78 & -102.0 & -128 & 14.900 \\
\hline AD-4 & 90 & 21 & -103.0 & -132 & 13.200 \\
\hline AD-5 & 60 & 45 & -99.5 & -13.2 & 12.400 \\
\hline AD-8 & 60 & 49 & -103.0 & -134 & 12.200 \\
\hline AD-9 & 110 & 33 & -1020 & -126 & 10.100 \\
\hline AD-10 & - & - & -975 & -13.2 & 11.200 \\
\hline $\mathrm{AD}-11$ & 90 & 30 & -1010 & -131 & 12.600 \\
\hline AD- 13 & 50 & 26 & -102.0 & -130 & 13,200 \\
\hline$A D-15$ & 60 & 16 & -104.0 & -13.0 & 13.600 \\
\hline AD- 17 & - & - & -105.0 & -128 & 13,400 \\
\hline AD- 18 & 100 & 15 & -102.0 & -130 & 10,300 \\
\hline AD-21 & - & - & -990 & -132 & 10.400 \\
\hline $\mathrm{AD}-23$ & 50 & 29 & -1030 & -13.4 & 14.200 \\
\hline AD-25 & - & - & -102.0 & -134 & 14.900 \\
\hline PM UE- $19 \mathrm{gs}$ & - & - & -113.5 & -14.5 & - \\
\hline PM UE-191 & - & - & -1095 & -14.0 & - \\
\hline PM UE-20a2 & - & - & -114.0 & -148 & 15,000 \\
\hline
\end{tabular}

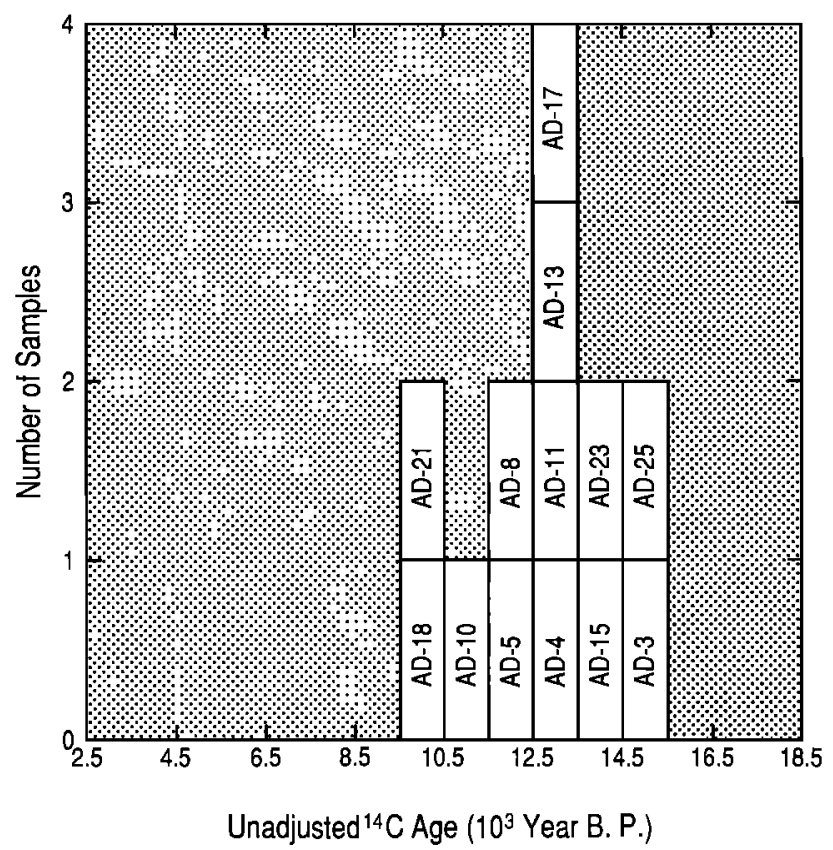

Fig. 7. Graph showing histogram of unadjusted ground-water ages from the Amargosa Desert. Data are for samples taken from aquifers not containing calcium carbonate.
Relation Of Ground Water Stable-Isotope Concentrations to the Meteoric Water Line $(M W L)$

The Oasis Valley and Fortymile Wash ground-water basin shown in Figure 8 was formally defined by Winograd and Thordarson [1975]. Physiographically, this basin is dominated by upland volcanic areas to the north (Pahute Mesa and Timber Mountain, Figure 8). Blankennagel and Weir [1973] suggested that water underlying Pahute Mesa moves southwestward and southward toward the Amargosa Desert through Oasis Valley, Crater Flat, and western Jackass Flats (Fortymile Canyon area). White and Chuma [1987] have confirmed Blankennagel and Weir's [1973] suggestion for the western part of the ground-water basin by determining that isotopically light ground water from Pahute Mesa discharges from springs in the headwaters of the Oasis Valley surface-drainage area. Using ground-water quality data from shallow wells in the Amargosa Desert south of Yucca Mountain, Claassen [1985] determined that Amargosa Desert ground water was recharged to valley fill primarily by overland flow in, or near, present-day stream channels.

Stable-isotope concentrations in ground water from Pahute Mesa and the Amargosa Desert (Table 3), Crater Flat (includes data from test wells USW H-6 and USW VH-1), Yucca Mountain, and Fortymile Canyon (Table 1a and $1 \mathrm{~b}$ ) were used to determine the atmospheric source (air-parcel trajectory) of water pumped from test wells located within $1 \mathrm{~km}$ of Yucca Mountain (Figure 6). The isotopic concentration in most ground-water plots is "underneath" the present-day mean meteoric water line (MWL); the $\delta \mathrm{D}$ excess value (d) for these waters is less than 10 (Figure 9). Ground water from Pahute Mesa has the most depleted isotopic values. The isotopically lightest sample (UE-20a2) is about 15,000 years old [White and Chuma, 1987]. Ground-water samples from the Fortymule Canyon area are 


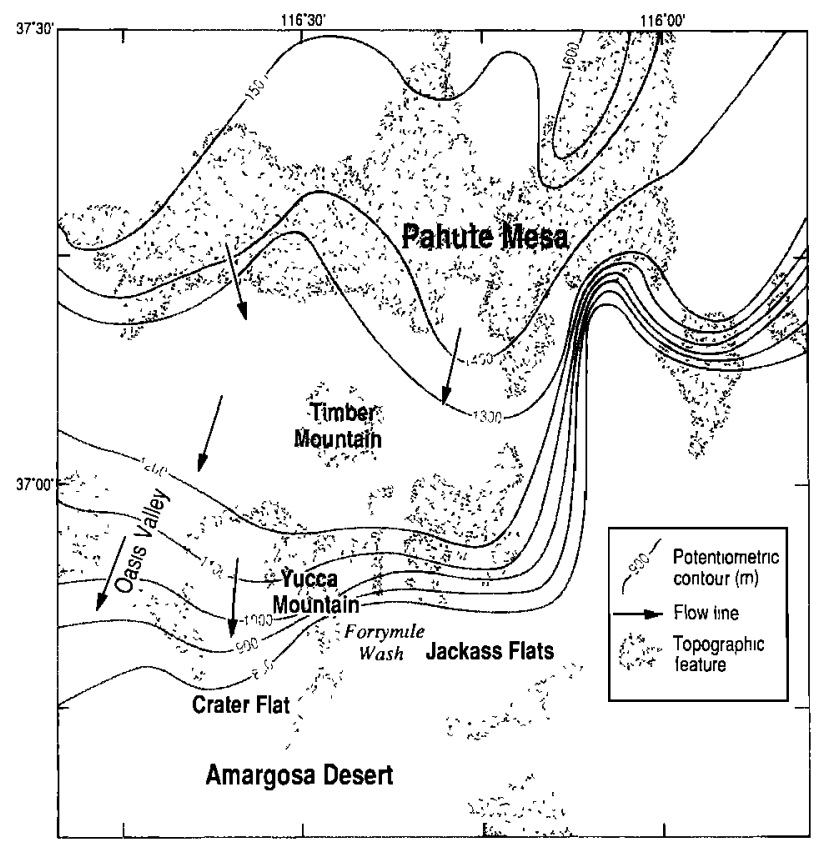

Fig. 8. Map showing generalızed ground-water flow field in the Yucca Mountain region.

sotopically the heaviest, and two samples from the Fortymile area (test well UE-29a \# 2) also are the youngest (approximately 4000 years old). Water from the Amargosa Desert displays the largest variation in d.

For ground water unaffected by hydrothermal processes, a distribution of $\delta \mathrm{D}-\delta^{18} \mathrm{O}$ lyıng below the MWL has usually been attributed to one of four processes: (1) incorporation of water reevaporated from over continents or lakes [Fontes and Gonfiantini, 1970], (2) fractionation during evaporation of rain or snow [Gat and Tzur, 1967], (3) decrease in the relative

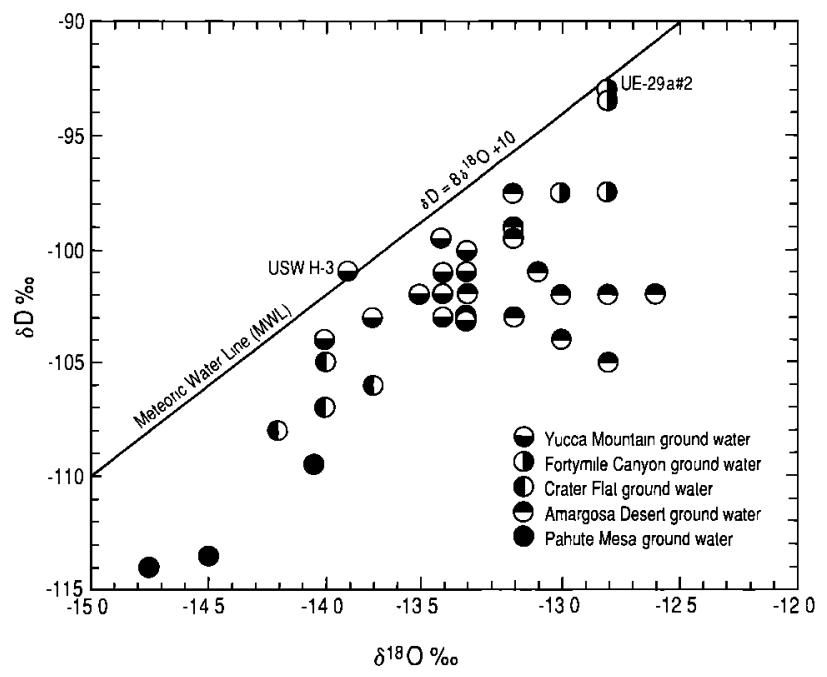

Fig. 9. Graph showing $\delta \mathrm{D}-\delta^{18} \mathrm{O}$ concentration in ground water from the Yucca Mountain region and its relation to the present-day mean meteoric water line (MWL). humidity of air over the moisture-source area [Merlivat and Jouzel, 1979; Sonntag et al., 1979], or (4) evaporation of water in the vadose zone.

During the Late Wisconsin, several large lakes were located less than $100 \mathrm{~km}$ to the southwest of Yucca Mountain (Figure 10). Evaporated lake water may have shifted the isotopic composition of precipitation in the Yucca Mountain area; however, the magnitude of this process remains unknown. Part of the scatter in $\delta \mathrm{D}-\delta^{18} \mathrm{O}$ and the large variation in $\mathrm{d}$ values for Amargosa Desert ground water is probably due to evaporation during or after infiltration of the relatively shallow ground water [Claassen, 1985]. However, in the case of Yucca Mountain ground water, a change in the relative humidity of air over the moisture-source area best accounts for the departure of Yucca Mountain ground water from the MWL. Ground-water samples from five test wells plot on or within $2 \% \circ \delta$ (the measurement precision) of the MWL (Figure 9). Although we cannot be completely certain, we contend this indicates that the evaporation process has had a minimal effect on the isotopic composition of ground water; i.e., ground water at the well USW H-3 site was recharged 18,000 yr B.P., but its isotopic content does not indicate the effects of evaporation. If this contention is valid, the $\delta^{18} \mathrm{O}-\delta \mathrm{D}$ concentration of the 4000 year old UE-29a \# 2 ground water that plots on the present-day MWL indicates that the humidity of the Pacific Ocean moisture-source region had probably reached present-day values by about $4000 \mathrm{yr}$ B.P. In support of this argument we note that ground water in the Yucca Mountain area is overlain by a thick $(500$ to $750 \mathrm{~m})$ unsaturated zone having a humidity of nearly 100 percent (E. Weeks, U.S. Geological Survey, written comm., 1988). Thus there exists little or no potential for evaporation of Yucca Mountain ground water.

The data of Figure 9 indicate that Yucca Mountain ground water may represent a mixture of Amargosa Desert and Crater Flat ground water. This implies that Yucca Mountain ground water was derived from a mixture of overland flow along Fortymile Canyon and ground-water flow from upland areas to the north (Pahute Mesa). To the extent that this argument is correct, the isotopic concentrations in, and radiocarbon activities of, Yucca Mountain ground water represent mixtures of isotopes from two recharge sources. In addition, if the humidity model of isotopic correction is correct, and only minor corrections need be made for evaporation, the oxygenisotope concentration in precipitation reaching the water table has increased systematically by about $1.7 \%$ from 18,500 to $9000 \mathrm{yr}$ B.P. (Figure 11). The scatter in the data is in part attributed to ground-water mixing that occurred during pumping, to mixing of ground-water from two recharge sources, and to differences in the seasonality (temperature and air-parcel trajectory) of recharge. Regression of the $\delta^{18} \mathrm{O}$ content of Yucca Mountain ground water against ${ }^{14} \mathrm{C}$ age (of samples greater than $9000 \mathrm{yr}$ B.P.) results in an $R^{2}$ of 0.71 indicating a significant degree of dependence of $\delta^{18} \mathrm{O}$ on age. However, regression of the $\delta^{18} \mathrm{O}$ content of Amargosa Desert ground water against ${ }^{14} \mathrm{C}$ indicates essentially no correlation $\left(R^{2}=0.10\right)$. We believe the poor correlation is due to evaporation of shallow Amargosa ground water.

\section{$\delta^{18} O$ and Sea-Surface Temperature in the Eastern Pacific Moisture Source} Region

To understand the climatic significance of a $1.7 \%$ increase in the $\delta^{18} \mathrm{O}$ of ground water, the $\delta^{18} \mathrm{O}$ history of the oceanic source region must also be known. The glacial-interglacial $\delta^{18} \mathrm{O}$ transition is recorded in the tests of Foraminifera preserved in deep-sea sediments. Mix and Ruddıman [1985] combined $\delta^{18} \mathrm{O}$ data sets from Atlantic-sediment cores to form a composite record of isotopic variation for 30,000 to $2000 \mathrm{yr}$ B.P. The composite record indicates a $1.1 \%$ o decrease in $\delta^{18} \mathrm{O}$ in the tests of planktonic Foraminifera from 14,000 to 9000 yr B.P. Data from the Pacific Ocean, the source area of most major storm systems reaching Nevada, are sparse. Broecker [1986] summarized glacial-interglacial $\delta^{18} \mathrm{O}$ changes that were measured in planktonic and benthic Foraminifera for the Atlantic and Pacific Oceans. $\mathrm{He}$ reported that the decrease in $\delta^{18} \mathrm{O}$ for planktonic Foraminifera between 18,000 and 0 yr B.P. was about $1.2 \%$ in the Pacific Ocean and about 


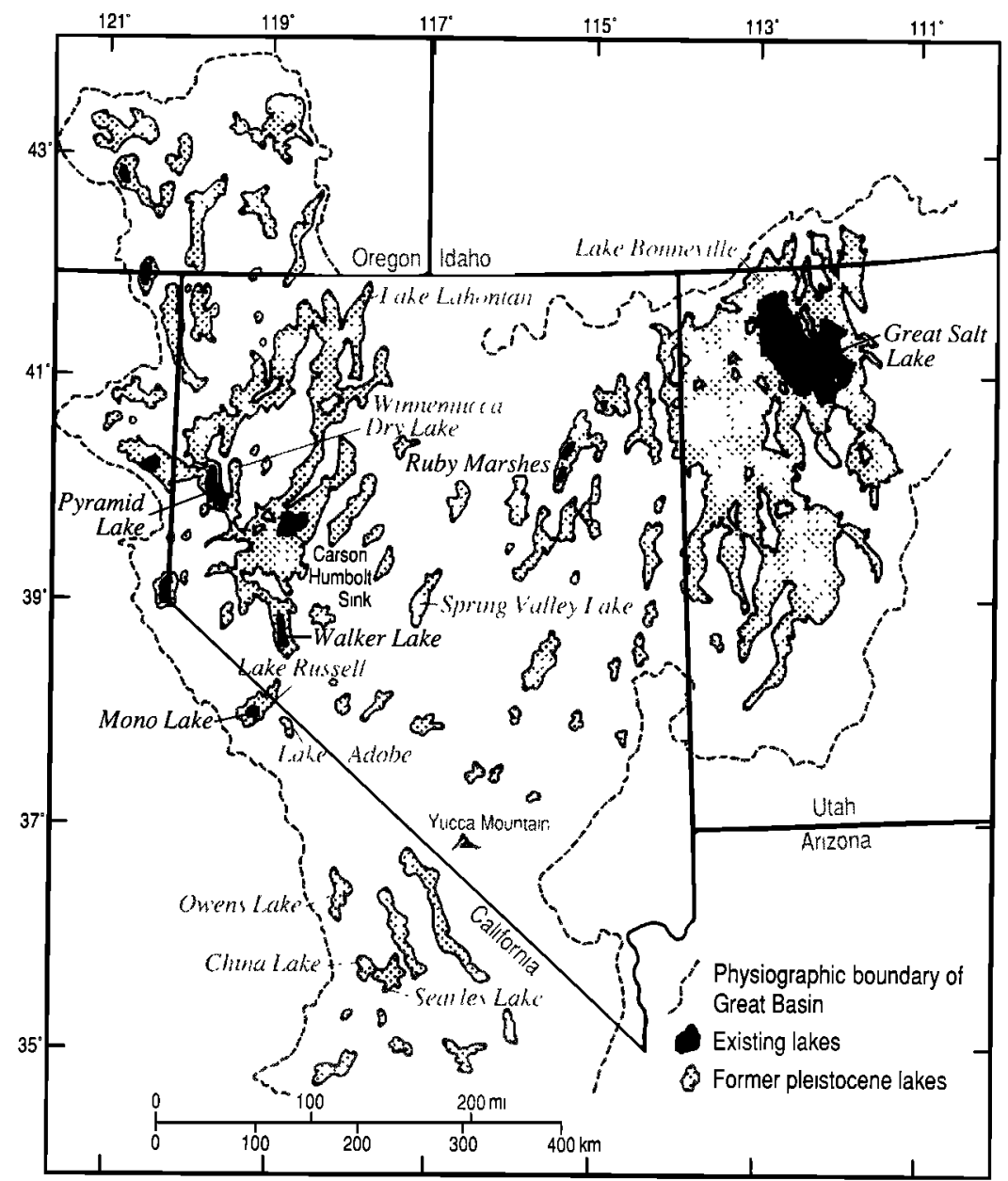

Fig. 10. Map showing location of lakes of assumed Late-Pleistocene age in the Great Basin [after Spaulding et al., 1983].

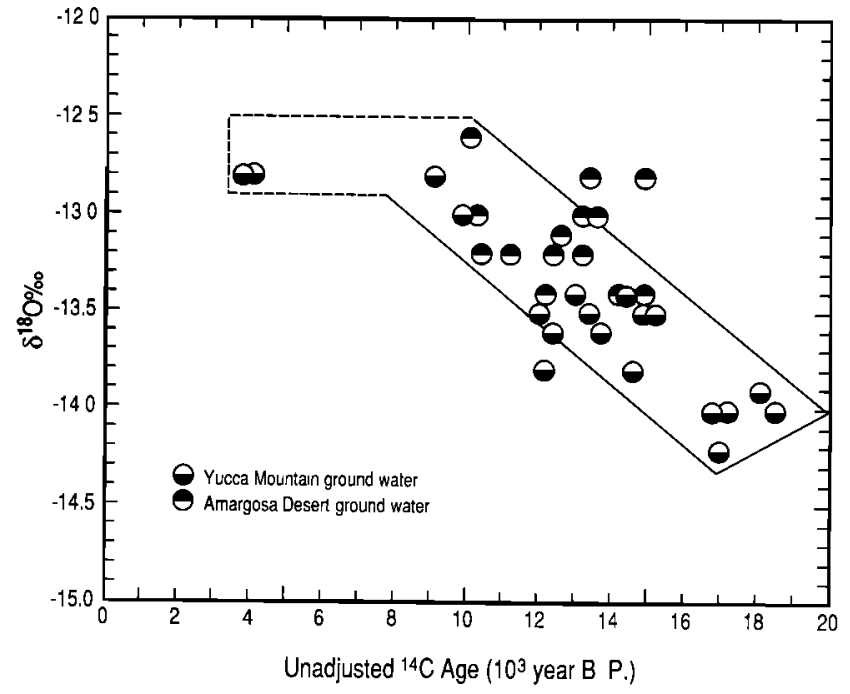

Fig. 11. Unadjusted $\delta^{18} \mathrm{O}$ of Yucca Mountain and Amargosa Desert ground water plotted as a function of unadjusted ${ }^{14} \mathrm{C}$ age.
$1.8 \%$ in the Atlantic Ocean. Bioturbation of low sedimentation rate cores (sedimentation rate averages about $2.5 \mathrm{~cm} / 10^{3} \mathrm{yr}$ ) from both oceans may have "smoothed" the $\delta^{18} \mathrm{O}$ record; therefore the observed decreases in $\delta^{18} \mathrm{O}$ may represent minımum values [Broecker, 1986]. In calculations that follow, a $1.1 \%$ decrease in $\delta^{18} \mathrm{O}$ of planktonic Foraminifera from the Pacific Ocean will be assumed to have occurred between 18,500 and 9000 yr B.P.

Sea-surface temperature (SST) reconstructions by CLIMAP [1981] of the Central Pacific Ocean $\left(10^{\circ}\right.$ to $40^{\circ} \mathrm{N}$. latitude) indicate surface water was about $1{ }^{\circ} \mathrm{C}$ warmer 18,000 years ago. Fractionation of $\delta^{18} \mathrm{O}$ between calcite and water decreases by $0.25 \%$ for each degree of heating [Friedman and $\left.O^{\prime} N e i l, 1977\right]$. Therefore the $\delta^{18} \mathrm{O}$ of Pacific Ocean surface water decreased about $1.3 \%$ between 18,500 and $9000 \mathrm{yr}$ B.P. During the time that precipitation in the Yucca Mountain area was becoming isotopically heavier (plus $1.7 \%$ ), the moisture-source region (Eastern Pacific Ocean) was becoming isotopically lighter (minus $1.3 \%$ ). This indicates that precipitation in the Yucca Mountain area underwent a 3.0\% increase in $\delta^{18} \mathrm{O}$ relative to the moisture-source area between 18,500 and $9000 \mathrm{yr}$ B.P.

To calculate the change in temperature associated with the change in $\delta^{18} \mathrm{O}$ between 18,500 and $9000 \mathrm{yr}$ B.P., the following theoretical relation, derived by Van der Straaten and Mook [1983], was used:

$$
\delta^{18} \mathrm{O}=0.56 \mathrm{~T}\left({ }^{\circ} \mathrm{C}\right)-12.7
$$


The calculation indicates that the temperature of condensation was about minus $5{ }^{\circ} \mathrm{C}$ about 18,500 yr B.P. and increased to about $0{ }^{\circ} \mathrm{C}$ by 9000 yr B.P. The temperature of condensation of the 4000 year-old-water from UE-29a \# 2 also was $0^{\circ} \mathrm{C}$, which indicates that the temperature of condensation of precipitation infiltrating to the water table did not change appreciably between 9000 and 4000 yr B.P.

The $5^{\circ} \mathrm{C}$ depression of air temperature at high altitudes 18,500 yг B.P. is similar to the results of Dohrenwend's [1984] study of nivation landforms in the high mountains of the Great Basin. He concluded that an approximate $7{ }^{\circ} \mathrm{C}$ full-glacial mean-annual temperature depression occurred throughout the Great Basin. The absolute values of the temperature of condensation at 18,500 and $9000 \mathrm{yr}$ B.P. are quite low when compared to present-day mean-annual air temperatures $\left(8\right.$ to $\left.10^{\circ} \mathrm{C}\right)$ recorded at Pahute Mesa (Jan-Hwa Chu, National Weather Service, Nuclear Support Office, NOAA, written comm., 1987). In fact the present average cold-season (November through February) temperature for Pahute Mesa is about $0{ }^{\circ} \mathrm{C}$. This indicates that condensation temperatures of recharge that occurred between 18,500 and 9000 yr B.P. were significantly lower than today's coldseason mean-monthly air temperatures.

In the following sections the stable-isotope concentration in precipitation will be compared with time, temperature, altitude, and air-parcel trajectories of present-day storm systems in order to determine the change in synoptic climate that caused the $3.0 \%$ shift in $\delta^{18} \mathrm{O}$. The change in synoptic climate is then used to suggest a hypothesis that accounts for the asynchroneity of lake and mountain-glacier cycles.

Relation of Stable-Isotope Concentrations in Precipitation to the PresentDay $M W L$

A plot of isotopic data for snow and rain collected during this study is shown in Figure 12. Precipitation samples were not analyzed for $\delta \mathrm{D}$ after March 10, 1986. The data indicate substantial variability along the MWL;

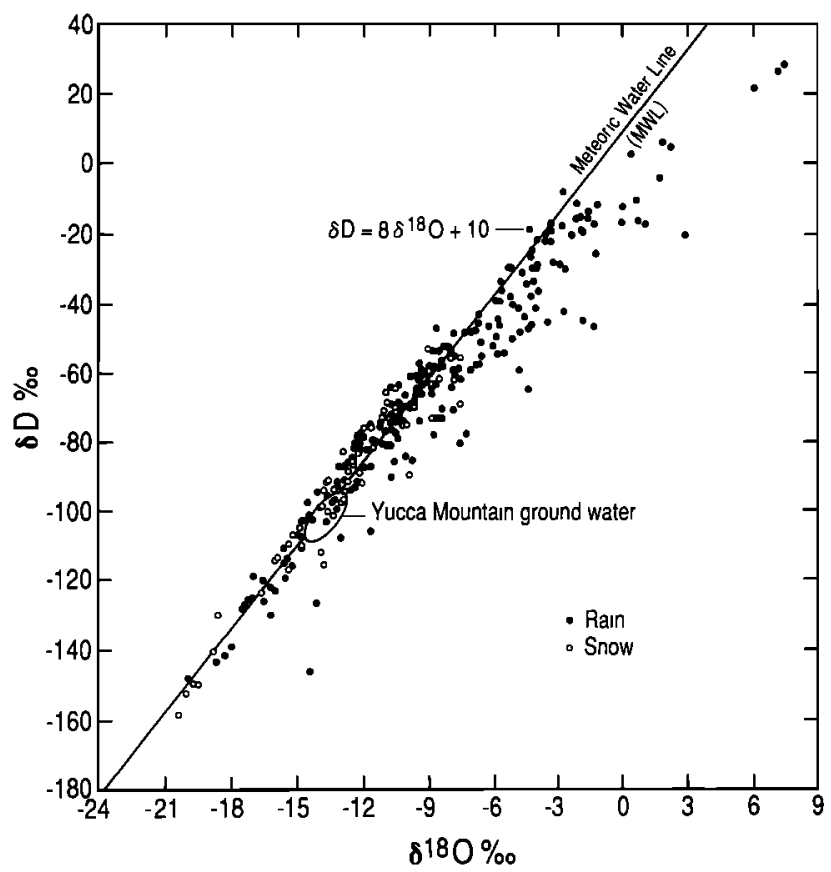

Fig. 12. $\delta \mathrm{D}-\delta^{1 \mathrm{~B}} \mathrm{O}$ of all precipitation samples collected in southern Nevada from about July 1983 through March 1986. e.g., $\delta^{18} \mathrm{O}$ ranges from minus 22.5 to plus $7.5 \%$ and a significant degree of departure from the MWL. On the scale of this plot the area occupied by Yucca Mountain, Crater Flat, and Fortymile Canyon ground water (Table 1) is relatively small. In addition, departure from the MWL by ground water is small relative to departure from the MWL for many precipitation events. Much of the variability in precipitation along, and normal to, the MWL is attributable to small amounts of summer rainfall that partially evaporated as it fell. A $\delta \mathrm{D}-\delta^{18} \mathrm{O}$ plot of all rainstorm events is shown in Figure 13. Linear regression of these data results in the best-fit equation:

$$
\delta \mathrm{D}=6.6 \delta^{18} \mathrm{O}-7.2
$$

However, when data for rain that fell in quantities less than $0.25 \mathrm{~cm}$ are excluded from the data set (thereby eliminating part of the bias due to evaporation), variability along, and normal to, the best fit regression line is significantly decreased and the regression equation,

$$
\delta \mathrm{D}=7.4 \delta^{18} \mathrm{O}+3.8
$$

begins to resemble the MWL. If data for precipitation in the form of snow (Figure 14) are analyzed separately (thereby eliminating most of the effects of evaporation), the best fit regression equation becomes almost identical to the MWL,

$$
\delta \mathrm{D}=8.0 \delta^{18} \mathrm{O}+8.9
$$

Of the several precipitation-collection sites, the $\mathrm{Ki}$ and Sandy sites are ones most relevant to an understanding of the origin of Yucca Mountain ground water. These sites are situated in areas that are most representative of sites that in the past contributed to the recharge of ground water now found in the Yucca Mountain area. The Ki site is located on Pahute Mesa at an altitude of $2145 \mathrm{~m}$, and the Sandy site is located on Yucca Mountain at an altitude of $1480 \mathrm{~m}$ (Figure 4).

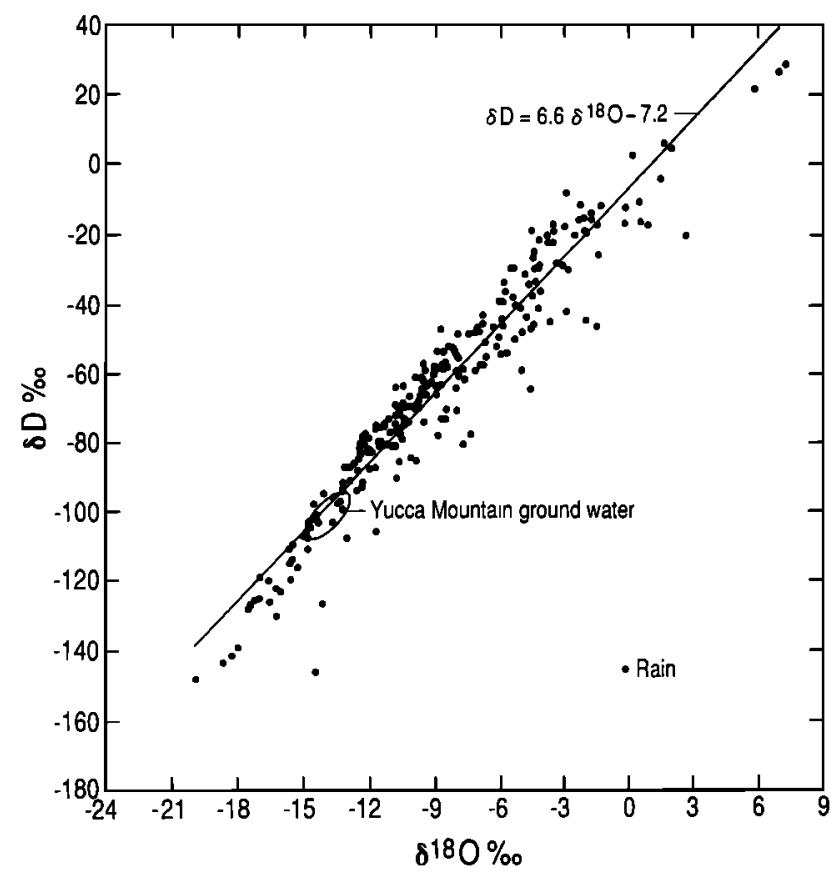

Fig. 13. $\delta \mathrm{D}-\delta^{18} \mathrm{O}$ of all rain samples collected in southern Nevada from about July 1983 through March 1986. 


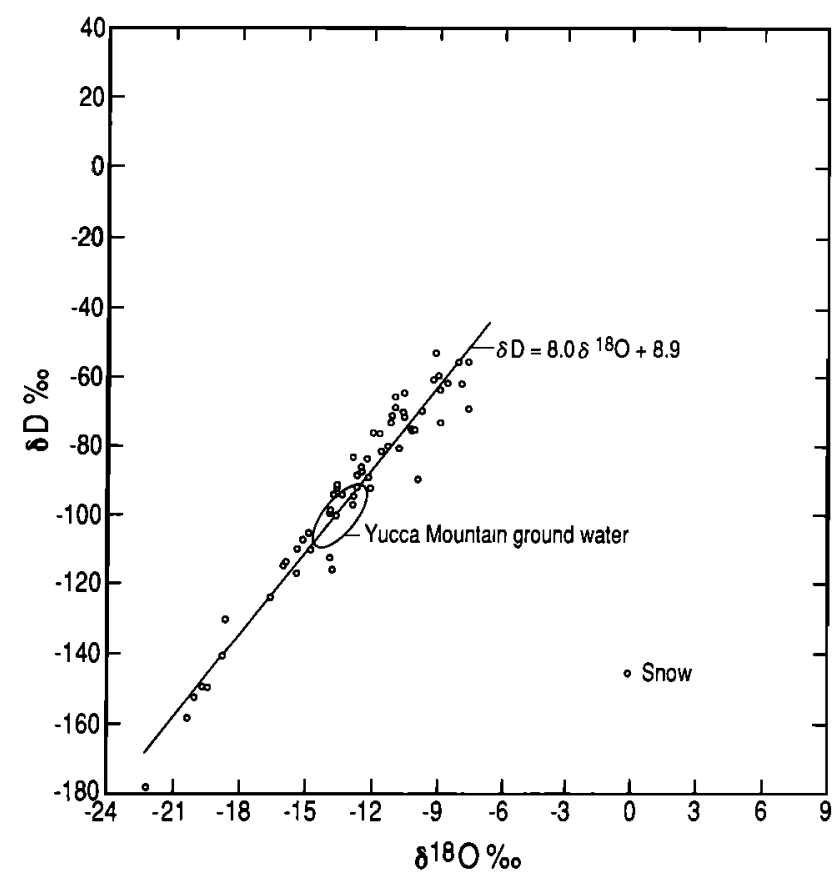

Fig. 14. $\delta \mathrm{D}-\delta^{18} \mathrm{O}$ of all snow samples collected at the Sandy site.

The isotopic compositions of rain and snow collected at both sites are plotted in Figures 15 and 16. The data indicate that $\mathrm{Ki}$, at the highest altitude, receives a greater proportion of its precipitation in the form of snow. To compare stable-isotope concentrations in precipitation collected at the various sites with the isotopic composition of ground water currently present in the Yucca Mountain area, the mean isotopic concentrations in snow and rain plus snow were calculated for each precipitation collection site. The use of weighted means is inappropriate because the seasonal distribution of modern precipitation cannot be assumed to be the same as during the last ground-water recharge cycle. The data indicate that the mean isotopic composition of present-day snow plus rain is significantly heavier ( 2 to $7 \%$ $\delta^{18} \mathrm{O}$ ) than the isotopic composition of Yucca Mountain ground water (Figures 17 and 18). However, the mean isotopic composition of snow alone is more similar to the isotopic concentration in Yucca Mountain ground water (differs by 0 to $4 \% \circ \delta^{18} \mathrm{O}$ ). This indicates that ground-water recharge in the Yucca Mountain area may have occurred in the form of snowmelt runoff.

Effect of Altitude and Temperature on the Isotopic Composition of Precipitation

The isotopic composition of precipitation differs from site to site as shown in Figures 17 and 18. Part of this difference probably is due to differences in record length; e.g., three of four sites (Sandy, Marge, Carolyn) on Yucca Mountain were decommissioned after 12 to 18 months of operation. The fourth site (Dianne) remained in operation for more than 3 years (Figure 5). The effect of altitude on the isotopic composition of precipitation is shown in Figure 19. Regression of mean $\delta^{18} \mathrm{O}$ data for each station indicates a dependence of $\delta^{18} \mathrm{O}$ on altitude of about minus $2.0 \%$ opr $1000 \mathrm{~m}$. A correlation between $\delta^{18} \mathrm{O}$ and air temperature of individual rainstorms was not found. Temperature data for snowstorms is not available because the tipping-bucket rain gages used to record the time and amount of rainfall were unheated and, therefore, were covered during the winter months. In

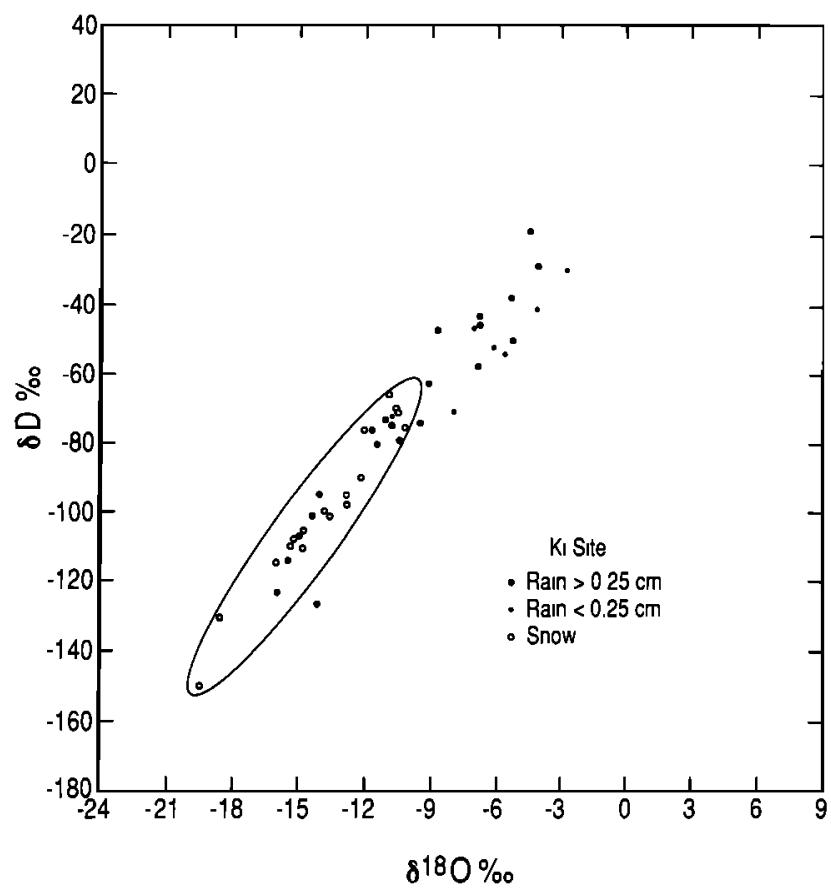

Fig. 15. $\delta \mathrm{D}-\delta^{18} \mathrm{O}$ of rain and snow samples collected at the Ki site located on Pahute Mesa.

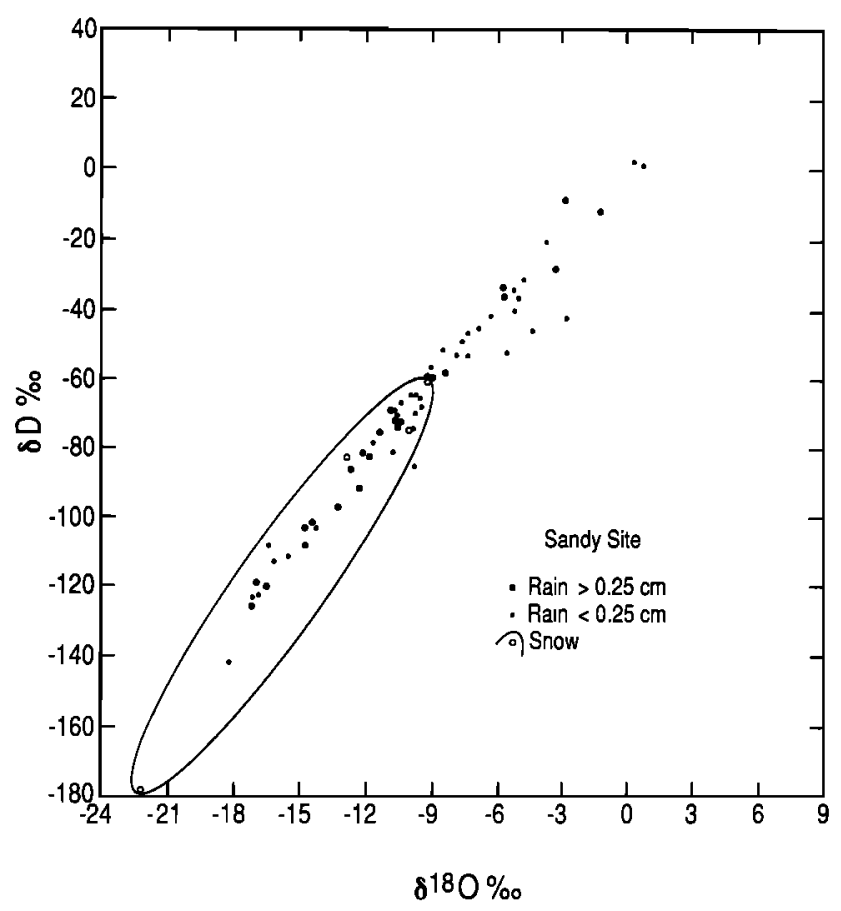

Fig. 16. $\delta \mathrm{D}-\delta^{18} \mathrm{O}$ of rain and snow samples collected at the Sandy site located on Yucca Mountain. 


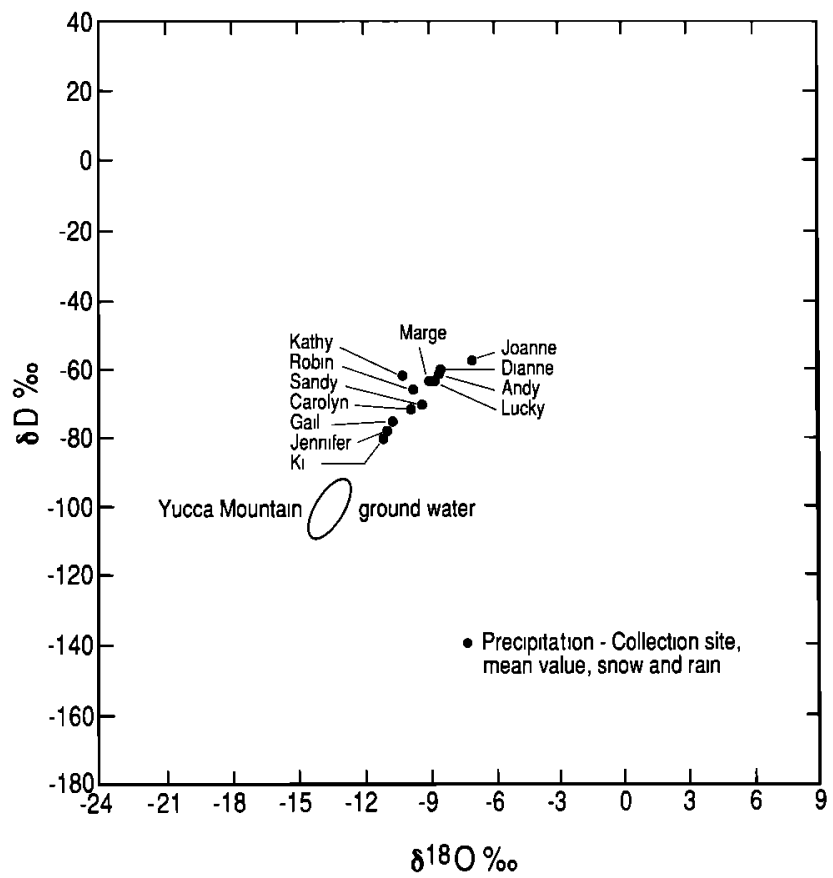

Fig. 17. Mean $\delta D-\delta^{18} O$ values of precipitation at 12 collection sites in southern Nevada compared to the $\delta \mathrm{D}-\delta^{18} \mathrm{O}$ concentration in Yucca Mountain ground water.

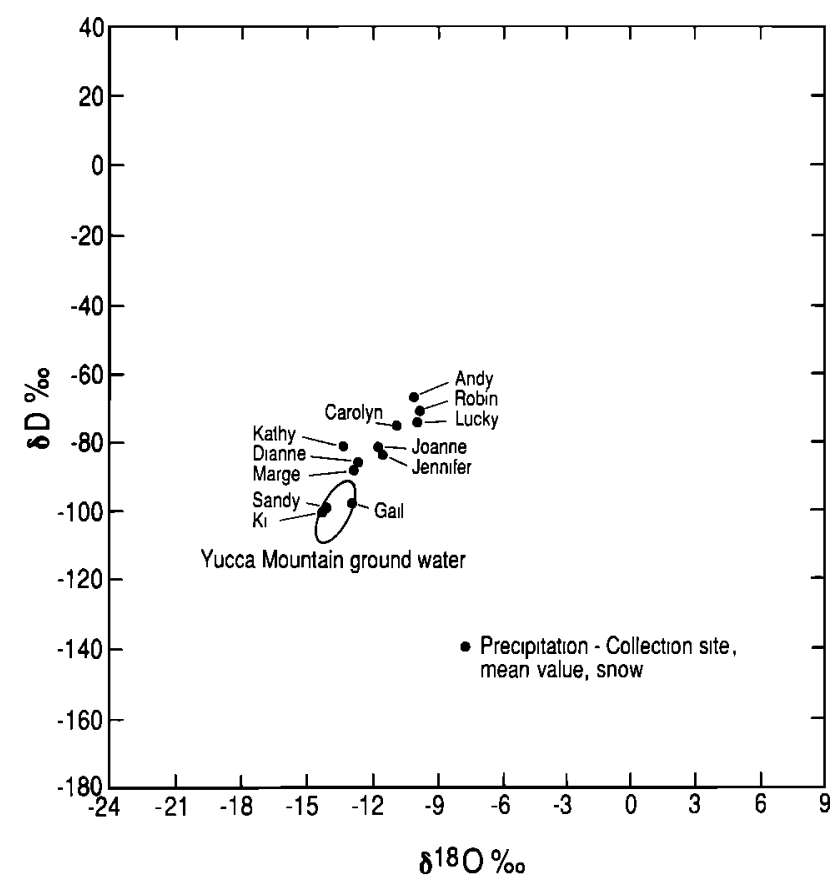

Fig. 18. Mean $\delta-\delta^{18} \mathrm{O}$ values of snow samples from 12 collection sites in southern Nevada compared to the $\delta-\delta^{18} \mathrm{O}$ concentration in Yucca Mountain ground water.

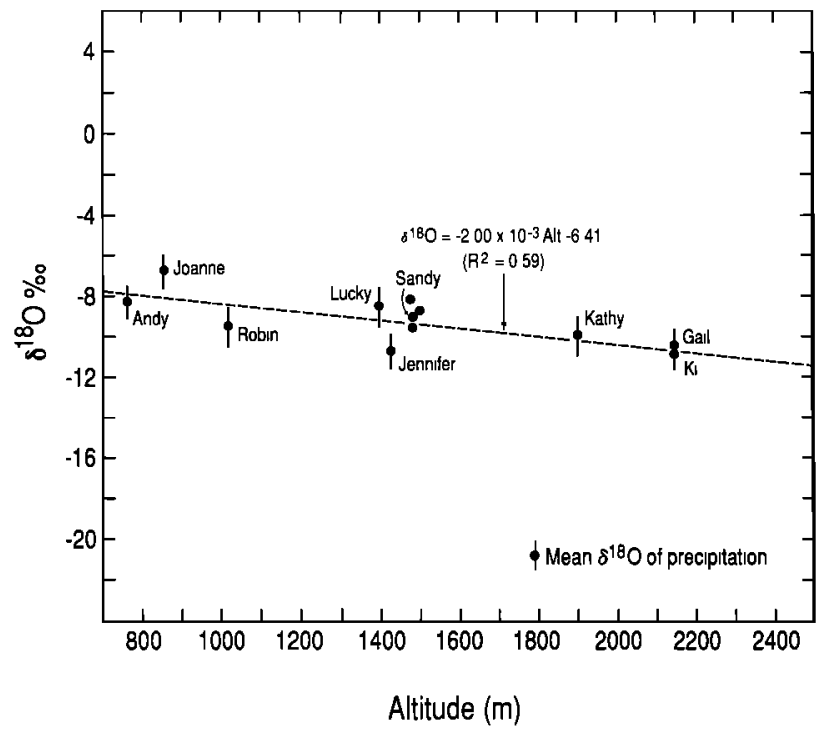

Fig. 19. Mean $\delta^{18} \mathrm{O}$ values in southern Nevada precipitation plotted as a function of site altitude.

any case the effect of altitude on the isotopic composition of precipitation is not considered to have had any effect on the isotopic composition of ground water recharged between 18,500 and 9000 yr B.P. in that the altitude of the site of recharge is not considered to have changed during that time.

\section{Air-Parcel Trajectories and the Isotopic Composition of Precipitation}

In his investigation of precipitation characteristics of the Great Basin, Houghton [1969] identtfied three principal components (Pacific, Gulf, Continental) all of which occur throughout the Great Basin, but each of which is dominant in certain regions of the Great Basin (Figure 20). The Pacific component, with a winter precipitation maximum, predominates in the western, northern, and southern regions. The Continental component, with a spring precipitation maximum, predominates in the central and eastern regions. The Gulf component, with a summer precipitation maximum, predominates in the southeastern region. Each of these components can be identified with recognizable circulation patterns and air-parcel trajectories.

The concept of air-parcel classification originated with Scandinavian meteorologists in the 1920's, and the principal air parcels affecting the Great Basin are designated as maritime polar (mP), maritime tropical (mT), continental tropical (cT), continental polar (cP), and arctic (A) [Byers, 1959]. Each of these air masses may generally be identified with source region, seasonal occurrence, and air-parcel trajectory (Figure 21). A subclassification derived by Bergeron [1930] includes $\mathrm{mP}_{k}$ and $\mathrm{cP}_{\mathrm{k}}$ polar air parcels that are colder than the the surface over which they flow. They are, thus, subject to rapid modification leading to thermal instability which often results in convective showers. When an air parcel passes through a region on the boundary of two source areas, or when the air parcel entraines moisture from two source regions (convergent flow), a mixed classification is used; e g., $\mathrm{mT} / \mathrm{mP}$. In this and following sections reference will be made to the jetstream. We will use this term to mean a quasihorizontal zone of maximum winds embedded in the mid-latitude westerles and concentrated in the high troposphere. Two jetstreams are distinguished. The predominant one, the polar front jetstream, is associated with the polar 

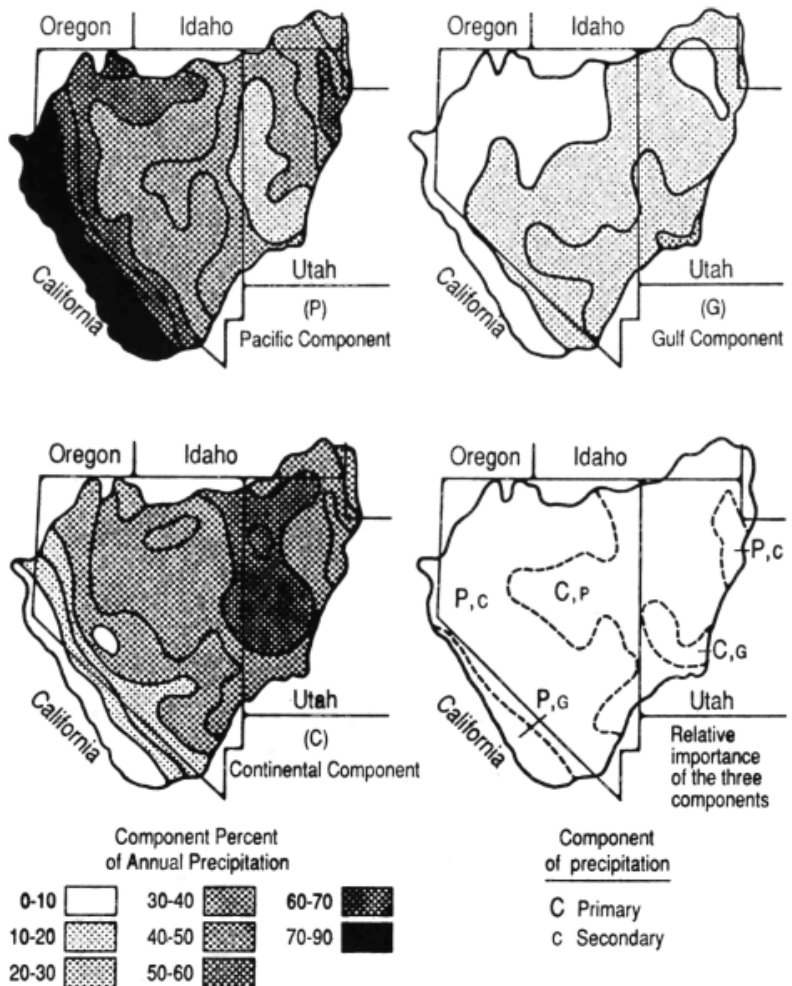

Fig. 20. Climatic gradients in the Great Basin [after Houghton, 1969].

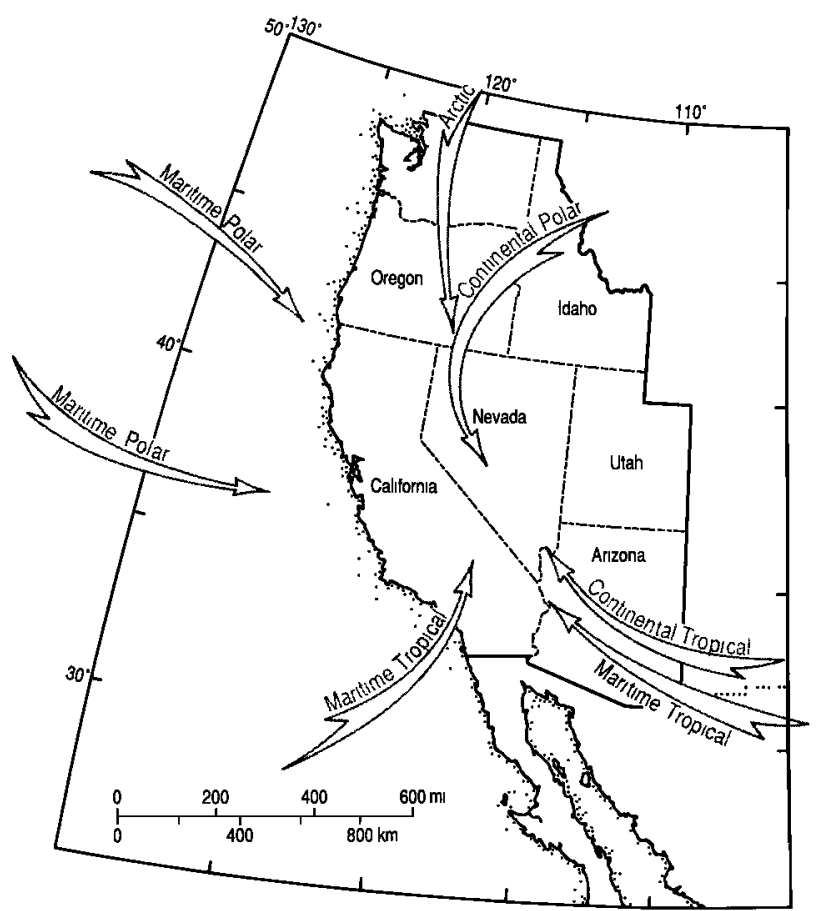

Fig. 21. Major air-flow patterns and air-parcel trajectories affecting California and the Great Basin [after Holmboe and Klieforth, 1957].

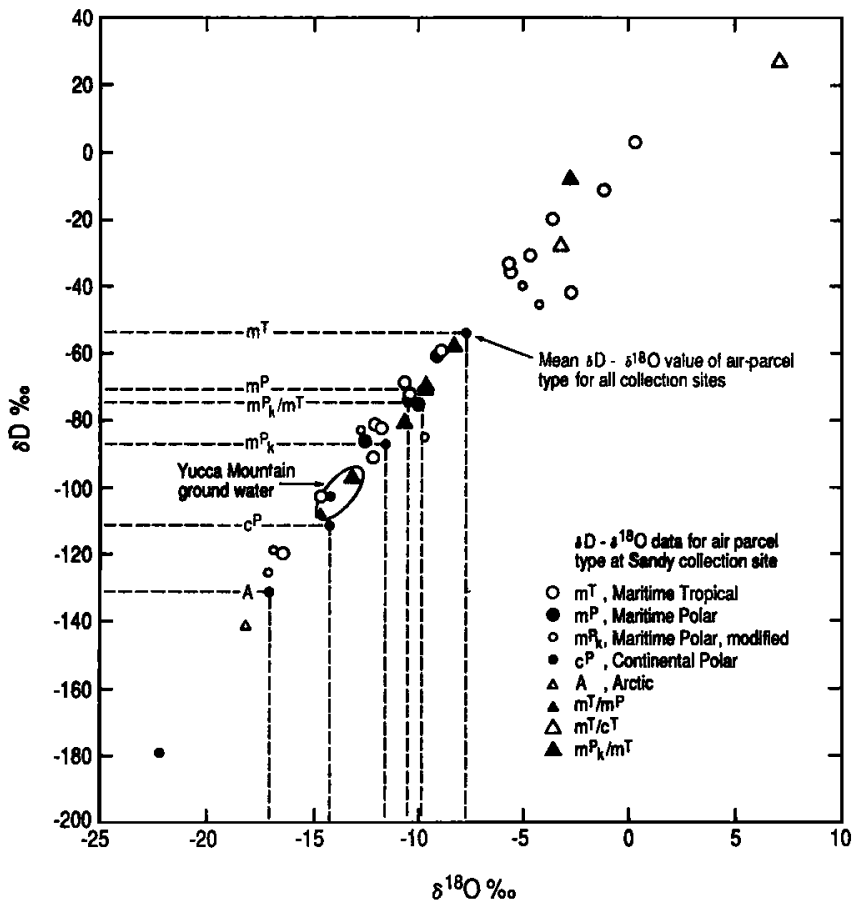

Fig. 22. $\delta-\delta^{18} \mathrm{O}$ of individual storms at the Sandy site classified by airparcel trajectory. Mean values of $\delta$ and $\delta^{18} \mathrm{O}$ for trajectory type for all sites are also shown.

front of middle and upper-middle latitudes. The subtropical jetstream is found between latitudes $20^{\circ}$ and $30^{\circ} \mathrm{N}$. [Huschke, 1959].

The stable-isotope concentration of precipitation at the Sandy site, classified by source region (Figure 22), indicates that air-parcel trajectories can also be classified by isotopic concentration. Mean isotopic values of end-member trajectories for all southern Nevada sites (listed in Table 4) are indicated in Figure 22 by dashes along the $\delta^{18} \mathrm{O}$ and $\delta \mathrm{D}$ axes. The $\delta^{18} \mathrm{O}$ of $\mathrm{mP}$ storms averages about $2 \%$ o lighter than $\mathrm{mT}$ storms, the $\delta^{18} \mathrm{O}$ of $\mathrm{mP}_{\mathrm{k}}$ storms averages about $4 \%$ lighter than $\mathrm{mT}$ storms, and the $\delta^{18} \mathrm{O}$ of cP storms averages about $7 \%$ o lighter than $\mathrm{m} T$ storms. Arctic trajectories have extremely light isotopic concentrations but data are available for only one storm.

Comparison of air-parcel isotope concentrations (Table 5) and the isotope concentration in Yucca Mountain ground water (Table 1a) indicates that isotopic distributions of $\mathrm{cP}, \mathrm{mP}$, and $\mathrm{mP}_{\mathrm{k}}$ air-parcel trajectories bracket the isotopic range of Yucca Mountain ground water. This indicates that Yucca Mountain ground water was not derived from monsoonal $(\mathrm{mT})$ air parcels. Instead, it appears that the oceanic moisture-source region for Pacific frontal systems moved southward between 18,500 and 9000 yr B.P.

\section{AGCM Experiments and the Synoptic Climate of the Great Basin}

Recent atmospheric global climate model (AGCM) simulations by Kutzbach and Wright [1985], Kutzbach and Guetter [1986], and Kutzbach [1987] provide insight into the mechanism and magnitude of synoptic climatic change that occurred in the southwestern United States during the past 18,000 years. AGCM experiments at 3000-year intervals for the past 18,000 years were done by Kutzbach and Guetter [1986] to estimate the magnitude, timing, and pattern of the climatic response to changes of orbital parameters 
TABLE 4. Storm Summary

$\left[\mathrm{A}=\right.$ Arctic; $\delta \mathrm{D}=$ del deuterium; $-=$ no data; $\mathrm{CF}=$ cold front $; \delta^{18} \mathrm{O}=$ del oxygen $18 ; \%$ = parts per mil; $\mathrm{cm}=$ centimeter; $\mathrm{mb}=\mathrm{m} 1 \mathrm{libar} ; \mathrm{PF}=$ polar front; $\mathrm{cP}_{\mathrm{k}}=$ contınental polar modıfied; $\mathrm{mP}=$ maritime polar; $\mathrm{cP}=$ continental polar; $\mathrm{mP}_{\mathrm{k}}=$ maritıme polar modified; $\mathrm{cT}=$ continental tropical; $\mathrm{mT}=$ maritime tropıcal, $\mathrm{R}=$ rain; $\mathrm{S}=$ snow; $\mathrm{SMOW}=$ standard mean ocean water]

\begin{tabular}{|c|c|c|c|c|c|c|c|}
\hline \multirow[b]{2}{*}{ Date } & \multirow[b]{2}{*}{$\begin{array}{c}\text { Flow type } \\
(500-\mathrm{mb} \text { level) }\end{array}$} & \multirow[b]{2}{*}{$\begin{array}{l}\text { Air-parcel } \\
\text { type }\end{array}$} & \multirow[b]{2}{*}{$\begin{array}{l}\text { Precip. } \\
\text { type }\end{array}$} & \multicolumn{2}{|c|}{$\begin{array}{l}\text { Precipitation } \\
\text { amount }(\mathrm{cm})\end{array}$} & \multicolumn{2}{|c|}{ Sandy site } \\
\hline & & & & $\begin{array}{c}\text { Sandy } \\
\text { site }\end{array}$ & $\begin{array}{c}\text { Gail } \\
\text { site }\end{array}$ & $\begin{array}{c}\delta^{18} \mathrm{O} \\
\% \% \\
\text { (SMOW) }\end{array}$ & $\begin{array}{c}\delta \mathrm{D} \\
\% \\
\text { (SMOW) }\end{array}$ \\
\hline
\end{tabular}

1983

$\begin{array}{ll}\text { Aug 9-10* } & \text { Summer monsoon } \\ \text { Aug 15-19* } & \text { Summer monsoon } \\ \text { Sep 25-26 } & \text { Low-latitude trough } \\ \text { Sep 30-Oct } 1 & \text { Cyclone } \\ \text { Nov 24-25 } & \text { Mid-latitude trough, CF } \\ \text { Dec 03-26* } & \text { Mid-latitude trough, CF }\end{array}$

\section{4}

Feb 10

Feb 13-16

Mar 14

Mar 29

Mar 30-Apr 1

Apr 6

Apr 19

Jun 14

Jun 23

Jun 30

Jul 2

Jul 12-15

Jul 16-18

Jul $18-20$

Jul 2!-22

Jul 25

Jul 27-28

Jul 29-3!

Jul 31-Aug 1

Aug 10-11

Aug 14-15

Aug 15-20

Nov 22-25

Nov 26-Dec 11

Dec 18-20

Dec 25-27

1985

Jan 7-8

Jan 26-27

Feb 2-3

Feb 20

Mar 11

Mar 14
Mid-latitude trough, CF

Mid-latıtude trough, CF

Mid-lattude trough, PF

Cold cyclone

Cold cyclone

Mid-latitude trough/cyclone

High-latitude trough/cyclone, $\mathrm{CF}$

Cyclone

Summer monsoon

Summer monsoon

Summer monsoon

Summer monsoon

Summer monsoon

Summer monsoon

Summer monsoon

Summer monsoon

Summer monsoon

Summer monsoon

Summer monsoon

Summer monsoon

Summer monsoon

Summer monsoon

Cyclone

Low-lattude trough/cyclone

High-lattude trough/cyclone

Low-lattude cyclone

Mid-latitude cyclone

Cyclone

High-latitude trough, CF

High-latitude trough

Cyclone

Cyclone

\begin{tabular}{|c|c|c|c|c|c|}
\hline $\mathrm{mT}$ & $\mathbf{R}$ & 0.83 & - & {$\left[\begin{array}{l}-1.2 \\
-3.6\end{array}\right.$} & $\begin{array}{l}-11 \\
-20\end{array}$ \\
\hline $\mathrm{mT}$ & $\mathbf{R}$ & 5.30 & - & $\begin{array}{r}-16.4 \\
\Gamma-12.1\end{array}$ & $\begin{array}{r}-119 \\
-81\end{array}$ \\
\hline $\mathrm{mT}$ & $\mathbf{R}$ & 1.19 & - & 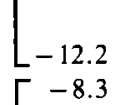 & $\begin{array}{l}-91 \\
-58\end{array}$ \\
\hline $\mathrm{mP}_{\mathrm{k}} \rightarrow / \mathrm{mT}$ & $\mathrm{R}$ & 1.07 & - & & -8 \\
\hline $\mathrm{mT} / \mathrm{mP}$ & $\mathbf{R}$ & 0.67 & - & -11.3 & -76 \\
\hline $\mathrm{mP}$ & $S$ & - & - & -9.1 & -60 \\
\hline
\end{tabular}

$\mathrm{mT} / \mathrm{mP}$

$\mathrm{mP}$

$\mathrm{mP}$

cP

$c P$

$\mathrm{mP}_{\mathrm{k}} \rightarrow / \mathrm{mT}$

$\mathrm{mP}_{\mathrm{k}}$

$\mathrm{cP}_{\mathrm{k}} \rightarrow / \mathrm{mT}$

$\mathrm{cT} / \mathrm{mT}$

$\mathrm{mT}$

$\mathrm{mT}$

$\mathrm{cT} / \mathrm{mT}$

$\mathrm{cT} / \mathrm{mT}$

$\mathrm{cT} / \mathrm{mT}$

$\mathrm{mT}$

$\mathrm{cT} / \mathrm{mT}$

$\mathrm{mT}$

$\mathrm{mT}$

mT

$\mathrm{cT} / \mathrm{mT}$

$\mathrm{mT}$

$\mathrm{mT}$

$\mathrm{mT} / \mathrm{mP}_{\mathrm{k}}$

$\mathrm{mP}_{\mathrm{k}} / \mathrm{mT}$

$\mathrm{mP}_{\mathrm{k}} / \mathrm{mT}$

mT

S $\quad 0.00$

$S \quad-$

000
0.00

0.00

$\begin{array}{ll}\mathrm{S} & 0.04 \\ \mathrm{R} / \mathrm{S} & 0.13\end{array}$

$\mathrm{R} / \mathrm{S} \quad 000$

R $\quad 0.00$

$\begin{array}{ll}R & 0.00\end{array}$

R $\quad 0.00$

$\mathrm{R} \quad 0.21$

R $\quad 0.64$

$\begin{array}{ll}\mathrm{R} & 0.00\end{array}$

$\mathrm{R}$

$118^{* *}$

0.00

1.35

$\mathrm{R}$

$\mathrm{R}$

0.90

-
-
0.50
0.02

0.02

0.02

000

000

017

0.17

058

0.12

6.10

1.55

[ 0.99

R $\quad 0.03$

R $\quad 5.93$

R $\quad 3.30$

$\mathrm{R} / \mathrm{S} \quad 2.20$

$\mathrm{R} / \mathrm{S} \quad 0.61$

$\mathrm{R} / \mathrm{S}] \quad 2.99$

0.18

1.17

11.28

6.64

L 021

0.00

4.22

3.73

$\begin{array}{rr}-10.0 & -75 \\ - & - \\ - & - \\ -22.2 & -179 \\ -96 & -70 \\ - & - \\ - & - \\ - & - \\ - & - \\ -2.8 & -42 \\ -3.2 & -28 \\ - & - \\ - & - \\ -11.8 & -82 \\ - & - \\ -5.6 & -36 \\ -8.9 & -60 \\ +7.0 & +27 \\ -8.7 & -55 \\ -10.4 & -72 \\ - & - \\ -14.4 & -102 \\ - & - \\ -14.7 & -103\end{array}$

$\mathrm{mP}_{\mathrm{k}}$
$\mathrm{cP}$
$\mathrm{A}$
$\mathrm{cP}$
$\mathrm{mP}$
$\mathrm{cP} / \mathrm{mP}$

S

$\left[\begin{array}{l}- \\ - \\ -\end{array}\right.$

$\mathrm{R} / \mathrm{S}$
$\mathrm{R} / \mathrm{S}$
$\mathrm{R} / \mathrm{S}$
$\mathrm{S}$
$\mathrm{R} / \mathrm{S}$
$\mathrm{R} / \mathrm{S}$

1.13

012

0.04

0.00

0.00

000 $\begin{array}{rr}-17.1 & -125 \\ -14.2 & -103 \\ -18.2 & -142 \\ - & - \\ - & - \\ - & -\end{array}$ 
TABLE 4. Storm Summary-Contınued

$\left[\mathrm{A}=\right.$ Arctic $; \delta \mathrm{D}=$ del deuterıum; $-=$ no data, $\mathrm{CF}=$ cold front $; \delta^{18} \mathrm{O}=$ del oxygen $18 ; \%$; front; $\mathrm{cP}_{\mathrm{k}}=$ continental polar modified; $\mathrm{mP}=$ maritime polar; $\mathrm{cP}=$ contınental polar; $\mathrm{mP}_{\mathrm{k}}=$ maritime polar modıfied; $\mathrm{cT}=$ continental tropical; $\mathrm{mT}=$ maritime tropical; $\mathrm{R}=$ rain; $\mathrm{S}=$ snow; SMOW = standard mean ocean water]

\begin{tabular}{|c|c|c|c|c|c|c|c|}
\hline \multirow[b]{2}{*}{ Date } & \multirow[b]{2}{*}{$\begin{array}{c}\text { Flow type } \\
\text { (500-mb level) }\end{array}$} & \multirow[b]{2}{*}{$\begin{array}{l}\text { Air-parcel } \\
\text { type }\end{array}$} & \multirow[b]{2}{*}{$\begin{array}{l}\text { Precip. } \\
\text { type }\end{array}$} & \multicolumn{2}{|c|}{$\begin{array}{l}\text { Precipitation } \\
\text { amount }(\mathrm{cm})\end{array}$} & \multicolumn{2}{|c|}{ Sandy site } \\
\hline & & & & $\begin{array}{l}\text { Sandy } \\
\text { site }\end{array}$ & $\begin{array}{l}\text { Gall } \\
\text { site }\end{array}$ & $\begin{array}{c}\delta^{18} \mathrm{O} \\
\% \% \circ \\
\text { (SMOW) }\end{array}$ & $\begin{array}{c}\delta \mathrm{D} \\
\% \text { oo } \\
\text { (SMOW) }\end{array}$ \\
\hline Mar 18-19 & Cyclone & $\mathrm{mP}_{\mathrm{k}}$ & $\mathrm{R} / \mathrm{S}$ & 021 & - & -9.7 & -85 \\
\hline Mar 27-29 & High-latitude trough, $\mathrm{CF}$ & $\mathrm{mP}$ & $R / S$ & 011 & - & -10.5 & -70 \\
\hline Apr $17-18$ & Cyclone & $\mathrm{mP}_{\mathrm{k}}$ & $\mathrm{R} / \mathrm{S}$ & 0.00 & 0.89 & - & - \\
\hline May $9-10$ & High-latitude trough/cyclone & $\mathrm{mP}_{\mathrm{k}}$ & $\mathrm{R}$ & 0.65 & 1.13 & -16.9 & -119 \\
\hline Jun $2-3$ & Cyclone & $\mathrm{mP}_{\mathrm{k}}$ & $\mathbf{R}$ & 000 & 006 & - & - \\
\hline Jun $24-25$ & $\mathrm{H}$ igh-latitute trough & $\mathrm{mP}_{\mathrm{k}}$ & $\mathbf{R}$ & 001 & 011 & -43 & -46 \\
\hline Jul 8-9 & Summer monsoon & $\mathrm{mT}$ & $\mathbf{R}$ & 000 & 009 & - & - \\
\hline Jul 10-11 & Summer monsoon & $\mathrm{mT}$ & $\mathbf{R}$ & 000 & 038 & - & - \\
\hline Jul 18-21 & Summer monsoon & $\mathrm{mT}$ & $\mathbf{R}$ & 089 & 7.35 & +0.3 & +2.9 \\
\hline Jul 25 & Summer monsoon & $\mathrm{mT}$ & $\mathbf{R}$ & 0.00 & 0.00 & - & - \\
\hline Jul 28-29 & Summer monsoon & $\mathrm{mT}$ & $\mathbf{R}$ & 0.00 & 0.00 & - & - \\
\hline Aug 26 & Summer monsoon & $\mathrm{mT}$ & $\mathbf{R}$ & 0.00 & 000 & - & - \\
\hline Sept $5-8$ & Cyclone & $\mathrm{mT} / \mathrm{mP}_{\mathrm{k}}$ & $\mathbf{R}$ & 000 & 0.03 & - & - \\
\hline Sept $18-19$ & Trough/cyclone & $\mathrm{mP}_{\mathrm{k}} / \mathrm{mT}$ & $\mathrm{R}$ & 1.65 & 354 & -11.8 & -83 \\
\hline Sept $27-28$ & Cyclone & $\mathrm{mT}$ & $\mathbf{R}$ & 0.01 & 0.63 & -5.5 & -52 \\
\hline Sept 30-Oct 1 & Cyclone/trough & $\mathrm{cP} / \mathrm{mP}_{\mathrm{k}}$ & $\mathbf{R}$ & 0.00 & 005 & - & - \\
\hline Oct $6-11$ & High-latitude trough/cyclone & $\mathrm{mP}_{\mathrm{k}}$ & $\mathrm{R} / \mathrm{S}$ & - & - & -5.1 & -40 \\
\hline Oct $21-22$ & High-latıtude trough, CF & $\mathrm{mP}$ & $R / S$ & - & - & - & - \\
\hline Oct 28 & Mid-latıtude trough, CF & $\mathrm{mP}$ & $\mathrm{R}$ & - & - & - & - \\
\hline Nov $9-13$ & Cyclone & $\mathrm{mP}_{\mathrm{k}}$ & $\mathrm{S}$ & - & - & -128 & -83 \\
\hline Nov 23-25 & High-latitude trough/cyclone & $\mathrm{mP}_{\mathrm{h}}$ & $\mathrm{R} / \mathrm{S}$ & - & - & - & - \\
\hline Nov 27-Dec 2 & High-/mid-latitude trough & $\mathrm{mP}$ & $R / S$ & - & - & - & - \\
\hline Dec 16 & Anticyclone & $\mathrm{cP}$ & $\mathrm{S}$ & - & - & - & - \\
\hline Dec 30 & Cyclone & $\mathrm{mP}$ & $S$ & - & - & - & - \\
\hline \multicolumn{8}{|l|}{1986} \\
\hline Jan $4-5$ & Mid-latıtude trough & $\mathrm{mP} / \mathrm{mT}$ & $\mathrm{R} / \mathrm{S}$ & - & - & -147 & -108 \\
\hline $\operatorname{Jan} 15$ & Low-lattude trough & $\mathrm{mT}$ & $R / S$ & - & - & - & - \\
\hline Jan 30-Feb 1 & Low-latitude trough & $\mathrm{mT}$ & $R / S$ & - & - & -105 & -74 \\
\hline Feb 3-4 & Mid-latitude trough, $\mathrm{CF}$ & $\mathrm{mT} / \mathrm{mP}$ & $\mathrm{R} / \mathrm{S}$ & 0.00 & 016 & - & - \\
\hline Feb 5 & High-latitude trough, CF & $\mathrm{mP} / \mathrm{cP}$ & $\mathrm{S}$ & 000 & 0.46 & - & - \\
\hline Feb $13-16$ & Low-latutude trough. CF & $\mathrm{mT}$ & $\mathrm{R} / \mathrm{S}$ & 1.56 & - & $\begin{array}{r}-47 \\
-10.7\end{array}$ & $\begin{array}{l}-31 \\
-69\end{array}$ \\
\hline Feb $17-19$ & Low-latıtude trough, $\mathrm{CF}$ & $\mathrm{mT}$ & $\mathrm{R} / \mathrm{S}$ & 0.00 & 1.58 & - & - \\
\hline Mar 2 & Low-latitude trough. CF & $\mathrm{mT}$ & $\mathbf{R}$ & 0.00 & 0.21 & - & - \\
\hline Mar 8-10 & Low-lattude trough, CF & $\mathrm{mT} / \mathrm{mP}_{\mathrm{k}}$ & $\mathrm{R} / \mathrm{S}$ & 2.18 & - & -13.2 & -97 \\
\hline Mar 12 & & $\mathrm{mT} / \mathrm{mP}_{\mathrm{k}}$ & $\mathrm{R} / \mathrm{S}$ & 0.08 & - & -107 & -81 \\
\hline Mar 14-16 & Mid-latitude trough, CF & $\mathrm{mP}_{\mathrm{k}}$ & $\mathrm{R} / \mathrm{S}$ & 0.08 & - & $\begin{array}{l}-167 \\
-122\end{array}$ & - \\
\hline Mar 29 & Cyclone & $\mathrm{mT}$ & $\mathbf{R}$ & 0.00 & - & - & - \\
\hline Apr 6 & Cyclone & $\mathrm{mT} / \mathrm{mP}_{\mathrm{k}}$ & $\mathrm{R} / \mathrm{S}$ & 0.26 & - & -5.7 & - \\
\hline Apr 16 & High-latitude trough, CF & $\mathrm{mP}$ & $\mathbf{R}$ & 000 & - & - & - \\
\hline May 4-6 & High-latitude trough/cyclone, CF & $\mathrm{mP}_{\mathrm{h}} / \mathrm{cP}_{\mathrm{h}}$ & $\mathrm{R} / \mathrm{S}$ & 031 & - & $\begin{array}{l}-11.4 \\
-11.7\end{array}$ & $\begin{array}{l}- \\
-\end{array}$ \\
\hline May 31-Jun 1 & Anticyclone & $\mathrm{mT} / \mathrm{cP}$ & $\mathbf{R}$ & 010 & - & +3.0 & - \\
\hline Jul 14-15 & Summer monsoon & $\mathrm{mT}$ & $\mathbf{R}$ & 0.14 & - & -69 & - \\
\hline Jul $21-23$ & Summer monsoon & $\mathrm{mT}$ & $\mathbf{R}$ & 107 & - & $\begin{array}{r}-8.6 \\
-100\end{array}$ & - \\
\hline Aug 9 & Summer monsoon & $\mathrm{cT} / \mathrm{mT}$ & $\mathbf{R}$ & 0.38 & - & +12 & - \\
\hline Aug 18 & Summer monsoon & $\mathrm{cT} / \mathrm{mT}$ & $\mathbf{R}$ & 043 & - & +0.7 & - \\
\hline Aug 26-27 & Summer monsoon & $\mathrm{cT} / \mathrm{mT}$ & $\mathbf{R}$ & 085 & - & -32 & - \\
\hline
\end{tabular}

* Exact tımıning of precipıtation not known for thıs perıod which was prior to installation of tıpping-bucket raın gage and micrologger

** Data from nearby station (Dianne) 
TABLE 5. Air-Parcel Stable-Isotope Statistics for Selected Southern Nevada Precipitation Collection Sites [ $\mathrm{n}=$ number of samples; $\mathrm{x}=$ mean; $\sigma=$ standard deviation; $-=$ insufficient date]

\begin{tabular}{|c|c|c|c|c|c|c|c|c|c|c|c|c|c|c|c|}
\hline \multirow{3}{*}{$\begin{array}{c}\text { Air-parcel } \\
\text { source } \\
\text { area } \\
\end{array}$} & \multicolumn{5}{|c|}{ All Sites } & \multicolumn{5}{|c|}{$\mathrm{Ki}$} & \multicolumn{5}{|c|}{ Sandy } \\
\hline & \multicolumn{3}{|c|}{$\delta^{18} \mathrm{O}(\% / \circ 0)$} & \multicolumn{2}{|c|}{$\delta \mathrm{D}(\% \circ)$} & \multicolumn{3}{|c|}{$\delta^{18} \mathrm{O}(\% \circ)$} & \multicolumn{2}{|c|}{$\delta \mathrm{D}(\% \circ)$} & \multicolumn{3}{|c|}{$\delta^{18} \mathrm{O}(\% \circ)$} & \multicolumn{2}{|c|}{$\delta \mathrm{D}(\% \circ)$} \\
\hline & $\mathbf{n}$ & $\bar{x}$ & $\bar{\sigma}$ & $\overline{\mathbf{x}}$ & $\bar{\sigma}$ & $\mathbf{n}$ & $\overline{\mathrm{x}}$ & $\bar{\sigma}$ & $\bar{x}$ & $\bar{\sigma}$ & $\mathbf{n}$ & $\bar{x}$ & $\bar{\sigma}$ & $\bar{x}$ & $\bar{\sigma}$ \\
\hline $\mathbf{A}$ & 5 & -17.3 & 2.2 & -131 & 20 & 1 & -19.4 & - & -150 & - & 1 & -18.2 & - & -142 & - \\
\hline $\mathrm{cP}$ & 15 & -14.5 & 3.9 & -112 & 29 & 3 & -14.1 & 2.2 & -100 & 21 & 2 & -18.2 & 5.7 & -141 & 54 \\
\hline $\mathrm{mP}$ & 34 & -9.9 & 3.1 & -72 & 20 & 5 & -11.0 & 5.5 & -90 & 25 & 4 & -10.6 & 1.5 & -73 & 11 \\
\hline $\mathrm{mP}_{\mathrm{k}}$ & 68 & -11.7 & 4.7 & -87 & 34 & 14 & -13.4 & 4.4 & -95 & 33 & 9 & -11.7 & 4.8 & -83 & 32 \\
\hline $\mathrm{mP} / \mathrm{mT}$ & 13 & -10.6 & 1.5 & -77 & 8 & 2 & -13.2 & 3.8 & -96 & 37 & 2 & -13.0 & 2.4 & -92 & 23 \\
\hline $\mathrm{mP}_{\mathrm{k}} / \mathrm{mT}$ & 37 & -10.5 & 4.0 & -75 & 30 & 6 & -11.5 & 2.4 & -86 & 12 & 8 & -9.6 & 3.9 & -70 & 31 \\
\hline $\mathrm{mT}$ & 121 & -7.7 & 4.4 & -54 & 27 & 16 & -7.9 & 3.8 & -59 & 25 & 21 & -8.1 & 4.4 & -57 & 32 \\
\hline $\mathrm{mT} / \mathrm{cT}$ & 28 & -5.4 & 6.0 & -49 & 36 & 3 & -7.2 & 3.4 & -54 & 18 & 5 & +0.5 & 4.2 & -0.5 & 39 \\
\hline
\end{tabular}

and glacial age boundary conditions. The results of those AGCM simulations for perpetual January and July climates, pertinent to this study, are shown in Figure 23.

Kutzbach [1987] summarizes the temporal behavior of the North American jetstreams for the months of July and January as follows: “ . . . In July, the split flow around the North American ice sheet at 18,000 yr B.P. persisted
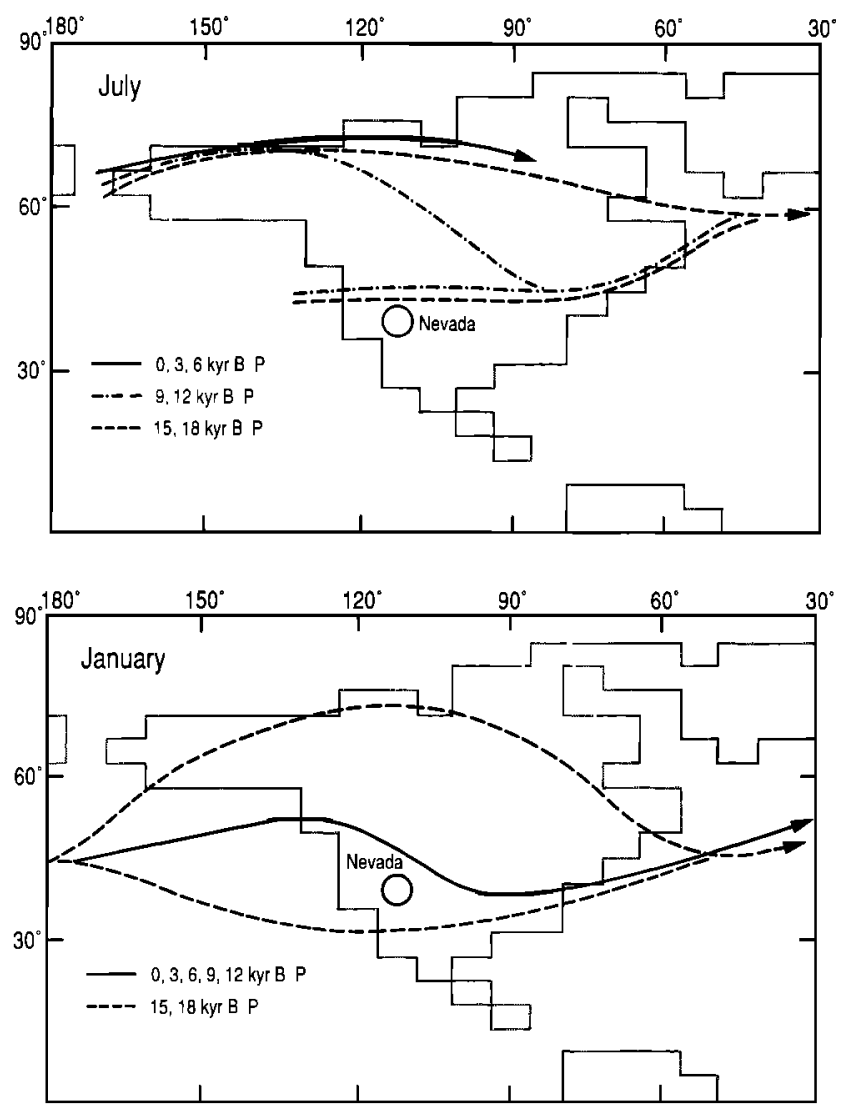

Fig. 23. Schematic location of core of maximum winds at $5.5 \mathrm{~km}$ at 3000 -year intervals, 18,000 to $0 \mathrm{yr}$ B.P., July and January [after Kutzbach, 1987]. at 15,000 yr B.P. with almost no change. By 12,000 yr B.P. two important changes had occurred. First, the northern branch of the jet moved south, over and along the southern flank of the ice sheet, and merged with the southern branch over the northeastern USA. This large change must have been related to the reduced size and height of the ice sheet. ... The jet at $9000 \mathrm{yr}$ B.P. followed about the same track as at $12,000 \mathrm{yr}$ B.P., but with weakened intensity. At $6000 \mathrm{yr}$ B.P., and thereafter, only a single jet core was simulated over Alaska and northem Canada, and winds were weak compared to earlier times. In summary the modern single jet core of July follows generally the same track as the northern branch of the split jet during July at the time of the glacial minimum. The southern branch of the split jet during glacial summers has no modern counterpart in July but resembles somewhat a modern January feature. The 12,000 to 9000 yr B.P. patterns are transitional between glacial maximum and modern patterns. ... In January, the split flow around the North American ice sheet and the intense North American/North Atlantic jet core at 18,000 yr B.P. persisted at 15,000 yr B.P. with almost no change. By 12,000 yr B.P. the flow had adjusted to a single core of maximum winds that followed the "west-coast ridge, east-coast trough" pattern of today; i.e., the patterns of $12,000,9000$, 6000,3000 , and 0 yr B.P. all have a single flow maximum rather than the split flow. At 12,000 yr B.P., however, the jet maximum was almost as strong as at 18,000 to $12,000 \mathrm{yr}$ B.P. (except in the southern USA); whereas, by $9000 \mathrm{yr}$ B.P., the jet core strength was signuficantly weakened and similar to that of today."

Since 1948 several authors [Riehl et al., 1954; Horn and Bryson, 1960; Sabbagh and Bryson, 1962; Pyke, 1972] have suggested that the progression of maximum precipitation along the western coast of North America is related to the mean position of the jetstream. Therefore in terms of precipitation, glacial age $(18,000$ to $15,000 \mathrm{yr}$ B.P.) summer climate was similar to present-day winter climate in the Great Basin [Antevs, 1952].

As discussed above, the change in $\delta^{18} \mathrm{O}$ concentration of water recharged in the Yucca Mountain area from 18,500 to $9000 \mathrm{yr}$ B.P. is thought to indicate a progressive warming of climate and a transition from $\mathrm{CP}$ and North Pacific mP air-parcel trajectories to central or even southern Pacific $\mathrm{mP}$ trajectories. We consider this time of transition to be related to changes in position and strength of the jetstream [Kutzbach and Guetter, 1986]. The recession of montane glaciers prior to the Lake Lahontan highstand 14,000 to $12,500 \mathrm{yr}$ B.P. is interpreted to have resulted in part from a progressive increase in the cold-season temperature. As pointed out by one of the reviewers (Fred Phillips, written comm., 1988), a small increase in winter temperature would probably not have a large effect on glacier mass balance. Glaciers are sensitive to two variables: winter precipitation and summer temperature. Therefore we suggest that glacier recession was due to an increase in the temperatures of both cold and warm seasons. The rise in Lake Lahontan between about 15,000 and 14,000 yг B.P. may have been caused 
by reduction of lake-surface evaporation rate and not by increased precipitation in the watershed area [Benson, 1986]. We associate this effectively wetter condition with the year-around proximty of the mean position of the jetstream. The near synchroneity of the northern Nevada lake-level cycle and the southern Nevada recharge cycle suggests that frontal systems associated with the jetstream spanned a large area.

\section{Conclusions}

A comparison of stable-isotope concentrations in precipitation and groundwater samples from the Yucca Mountain area of Nevada indicates that:

(1) The stable-isotope concentrations of rain that falls today in amounts greater than $0.25 \mathrm{~cm}$ and of snow plot close to the mean MWL.

(2) The $\delta^{18} \mathrm{O}$ concentrations in air-parcel trajectories from $\mathrm{cP}, \mathrm{mP}$, and $\mathrm{mP}_{\mathrm{k}}$ moisture-source areas bracket the stable isotopic range of Yucca Mountain ground water.

(3) Precipitation from A, cP, and $\mathrm{mP}$ moisture-source areas occurs during winter mostly in the form of snow.

(4) The $\delta^{18} \mathrm{O}$ of precipitation in southern Nevada decreases by about $2.0 \%$ for each $1000-\mathrm{m}$ increase in ground-surface altitude. This is due to the fact that snow makes up a large part of precipitation at higher (colder) altitudes.

(5) Yucca Mountain ground water (excepting samples from wells USW H-3 and UE-29a \#2) has deuterium excess values less than 10 . The deviation from the MWL is thought to indicate change in the relative humidity of the moisture source area.

(6) Most of the recharge in the Yucca Mountain and Amargosa Desert areas of southern Nevada occurred between 18,500 and $9000 \mathrm{yr}$ B.P. AGCM experiments for this time period [Kutzbach, 1987] indicate that the source area of precipitation was the high- and mid-latitude eastern Pacific Ocean. These experiments are consistent with the results of the isotope data that indicate that the moisture source region in the eastern Pacific moved southward between 18,500 and 9000 yг B.P.

(7) The $\delta^{18} \mathrm{O}$ concentration of Yucca Mountain and Amargosa Desert ground water increased by about $1.7 \%$ from 500 to 9000 yr B.P. During the same time period, the $\delta^{18} \mathrm{O}$ concentration in Central Pacific surface water decreased by about $1.3 \%$. Therefore a shift of about $3.0 \%$ oc curred in the $\delta^{18} \mathrm{O}$ concentration of precipitation infiltrating to the groundwater table, relative to the $\delta^{18} \mathrm{O}$ concentration in the moisture-source area.

(8) Between 18,500 and $9000 \mathrm{yr}$ B.P. the temperature of condensation increased by about $5{ }^{\circ} \mathrm{C}$; i.e., from about minus $5{ }^{\circ} \mathrm{C}$ to $0{ }^{\circ} \mathrm{C}$. The low absolute values of this temperature range indicate that infiltration of precipitation to the ground-water table occurred by snowmelt runoff. This conclusion is consistent with the results obtained by Claassen [1985] in a study of the age and source of ground water recharged to the Amargosa Desert area, in a study by Simpson et al. [1972] of the seasonality of recharge in the Tucson ground-water basin, and with the findings of Winograd and Riggs [1984] who showed that recharge to spring systems in the Spring Mountains area of southern Nevada occurs by infiltration of winter-season precipitation.

(9) Most of the ground water that underlies Yucca Mountain probably was recharged by infiltration of snowmelt along the bottom of Fortymile Canyon, however, some Yucca Mountain ground water may have been recharged by mixtures of upland- and wash-type ground water. Significant recharge has not been noted during times of recent flooding of Fortymile Canyon. This suggests that times of flooding must have lasted much longer in the 18,500 to $9000 \mathrm{yr}$ B.P. time interval.

(10) Although the potential for ground-water mixing during pumping complicates the argument, recharge of ground water in southern Nevada appears to have occurred nearly synchronously with the last lake cycle in the Lahontan basin of northern Nevada. Both the last lake cycle and groundwater recharge, events indicating regional-scale change in the hydrologic balance, occurred during the last glacial-interglacial transition.
(11) The prehighstand-lake recession of northern Nevada glaciers is attributed, in part, to a year-round warming trend that occurred between 18,500 and 9000 yr B.P.

(12) AGCM simulations by Kutzbach and Guetter [1986] and Kutzbach [1987] provide an integrating mechanism that accounts for the near synchroneity of continental ice sheet, lake, and ground-water cycles; $1 . e .$, the position and persistence of the jetstream (which is associated with the progression of precipitation and cloudiness) is substantially affected by the size and shape of the continental ice sheet.

Appendix. One of the reviewers (Isaac Winograd, U.S. Geological Survey, written comm., 1987) has suggested that the ${ }^{3} \mathrm{H}$ concentration in samples from UE-29a \#2 may have resulted in the mixing of old and modern ground water; 1.e., the samples contain modern prenuclear age ${ }^{3} \mathrm{H}$ and ${ }^{14} \mathrm{C}$. If it is assumed that the old water was recharged about 9000 yr B.P. (the age of water from nearby well J-12), a mass-balance calculation indicates that about 57 percent of the UE-29a \# 2 sample is old ground water, and 43 percent is modern ground water. A further calculation indicates that the hypothetical prenuclear age modern water contains approximately $86 \mathrm{pCi}$ $\mathrm{L}^{-1}$ of ${ }^{3} \mathrm{H}$. This amount of ${ }^{3} \mathrm{H}$ is too large by at least a factor of 4 to have originated in the modern prenuclear age and indicates that mixing of ground water has not occurred.

Test-well data (Table 1a) indicate that the water table is near the land surface at the site of UE-29a \# 2. During 1958-1968, ${ }^{3} \mathrm{H}$ concentrations in the northern hemisphere reached approximately $6500 \mathrm{pCi} \mathrm{L}^{-1}$ as the result of atmospheric testing. It is suggested that contamination of well UE-29a \# 2 occurred as the result of diffusion of ${ }^{3} \mathrm{H}$ across the arr-water interface since the initiation of atmospheric testing. However, this does not imply that ${ }^{14} \mathrm{C}$ has diffused into the aquifer. The partial pressure of $\mathrm{CO}_{2}$ in the overlying unsaturated zone $1510^{-3}$ (Ed Weeks, U.S. Geological Survey, written comm., 1988) and the partial pressure of $\mathrm{CO}_{2}$ in UE-29a \#2 ground water is $10^{-2}$ (EQ3NR calculation, this study). This indicates that the potential for carbon migration is upward from the ground water to the unsaturated zone and not in the opposite direction.

Unlike the mixing hypothesis, the ${ }^{3} \mathrm{H}$-diffusion hypothesis does not require that significant amounts of ground-water recharge take place in the Fortymile Wash area today. This is consistent with the results of ongoing neutron-hole studies of moisture transport in the Fortymile Wash area that indicate that present-day floodwater does not penetrate to the water table [Alan Flint, U.S. Geological Survey, written comm., 1987]. Given the above observations, it would appear that mixing of ground water of differing ages has not significantly altered the distribution of ground-water ages in the Yucca Mountain area.

Acknowledgments. The authors wish to express appreciation to Frederick Pallet, Irving Friedman, Robert Thompson, Isaac Winograd of the U.S. Geological Survey, John Kutzbach of the University of Wisconsin, Fred Phillips of the New Mexico Institute of Mining and Technology as well as one anonymous reviewer for their constructive reviews of the manuscript. Thanks also are due to Wendy Milne and My-Lien Nguyen both of the U.S. Geological Survey for their assistance in preparing the preliminary graphics.

\section{References}

Antevs, E., Cenozoic climates of the Great Basin, Geolgische Rundschau, v. 40, p. 94-108, 1952.

Benson, L. V., The sensitıving of evaporation rate to climate change; results of an energy-balance approach, U.S. Geological Survey Water Resources Investigations Report 86-4148, 40 p., 1986.

Benson, L. V., and McKinley, P. W., Chemical composition of ground water in the Yucca Mountain area, Nevada, 197-184, U.S. Geological Survey open-file report, 85-484, 10 p., 1985. 
Benson, L. V., Robison, J. H., Blankennagel R. K., and Ogard, A. E., Chemical composition of ground water and the locations of permeable zones in the Yucca Mountain area, Nevada, U.S. Geological Survey openfile report, 83-854, 19 p., 1983.

Benson, L. V. and Thompson, R. S., Lake-level variation in the Lahontan Basin for the past 50,000 years, Quaternary Research, v. 28, p. 69-85, 1987a.

Benson, L. V. and Thompson, R. S., The physical record of lakes in the Great Basin, in North America and Adjacent Oceans During the Last Deglaciation, edited by W. F. Ruddiman and H. E. Wright, Jr., The Geology of North America, K-3, p. 241-260, Geological Society of America, 1987b.

Bergeron, T., Rechtlinien einer dynamishcen klimatologie, Meteorology Journal, v. 47, p. 246-242, 1930.

Blankennagel, R. K. and Weir, J. E., Jr., Geohydrology of the eastern part of Pahute Mesa, Nevada test site, Nye County, Nevada, U.S. Geological Survey Professional Paper, 712B, 1973.

Broecker, W. S., Oxygen isotope constraints on surface ocean temperatures, Quaternary Research, v. 26, p. 121-134, 1986.

Byers, H., Air masses and their structure, in General Meteorology, chap. 14, p. 335-342, McGraw Hill, N.Y., 1959.

Claassen, H. C., Sources and mechanisms of recharge for ground water in the west central Amargosa Desert, Nevada: A geochemical interpretation, U.S. Geolological Survey Professional Paper, 7I2F, 31 p., 1985.

CLIMAP Project Members, Seasonal reconstructions of the earth's surface at the last glacial maximum, Geological Society of America, Map and Chart Series, $M C-36$, p. 1-18, 1981.

Currey, D. R., Isochromism of final Pleistocene lakes in the Great Salt Lake and Carson Desert regions of the Great Basin, American Quaternary Association Programs and Abstracts of the Tenth Biennial Meeting, p. 117, 1988.

Currey, D. R., and Oviatt, C. G., Durations, average rates, and probable cause of Lake Bonneville expansions, stillstands, and contractions during the last deep-lake cycle, 32,000 to 10,000 years ago, in Problems Of and Prospects For Predicting Great Salt Lake Levels: Center for Public Affairs and Administration, edited by P. A. Kay and H. F. Diaz, University of Utah, p. 1-9, 1985.

Dohrenwend, J. C., Nivation landforms in the western Great Basin and their paleoclimatic significance, Quarternary Research, v. 22, p. 275-288, 1984.

Dorn, I. R., Turrin, B. D., Jull, A. J. T, Linick, T. W., and Donahue, D. J., Radiocarbon and cation-ratio ages for rock varnish on Tioga and Tahoe morainal boulders of Pine Creek, eastern Sierra Nevada, Calıfornia, and their paleoclimatic implications, Quarternary Research, v. 28 , p. 38-49, 1987.

Fontes, J. Ch. and Gonfiantini, R., Composition sotopique et origine de la vapeur d'eau atmospherique dans la region du Lac Leman, Earth Planetary Science Letter, v. 7, p. 325-329, 1970.

Friedman, I. and O'Neil, J. R., Compilation of stable 1sotope fractionation factors of geochemical interest, U.S. Geological Survey Professional Paper, 440-KK, 211 p., 1977.

Holmboe, J. and Klieforth, H., The effect of the Sierra Nevada on a Pacific storm, investigations of Mountain Lee Waves and the air flow over the Sierra Nevada, Final Rept. Contract AF 19, 604-728, Meteorology Department, University California Los Angeles, p. 99-117, 1957.

Horn, L. H. and Bryson, R. A., Harmonic analysis of the annual march of precipitation over the United States, Annals of the Association of Amertcan Geography, v. 50, p. 157-171, 1960.

Huschke, R. E., Glossary of Meteorology, American Meteorology Society, 1959.

Kutzbach, J. E., Model simulations of the climatic patterns during the deglaciation of North America, in North America and Adjacent Oceans During the Last Deglaciation, edited by W. F. Ruddıman and H. E.
Wright, Jr., The Geology of North America, K-3, p. 425-446, Geological Society America, 1987.

Kutzbach, J. E. and Guetter, P. J., The influence of changing orbital parameters and surface boundary conditions on climate simulations for the past 18,000 years, Journal of Atmospheric Science, v. 43, p. 1726-1759, 1986.

Kutzbach, J. E., and Wright, H. E., Jr., Simulation of the climate of 18,000 yr B.P.: Results for the North American/North Atlantic/European Sector, Quarterly Science Review, v. 4, p. 147-187, 1985.

Lao, Y., and Benson, L. V., Uranium-series age estimates and paleoclimatic significance of Pleistocene tufas from the Lahontan Basin, California and Nevada, Quarternary Research, v. 30, p. 165-176, 1988.

Manabe, S, and Broccoli, A. J., The influence of continental ice sheets on the climate of an ice age, Journal of Geophysical Research, v. 90, p. $2167-2190,1985$.

Merlivat, L., and Jouzel, J., Global climate interpretation of deuteriumoxygen 18 relationship for precipitation, Journal of Geophysical Research, v. 84, p. $5029-5033,1979$.

Milne, W. K., Benson, L. V., and McKinley, P. W., Isotope content and temperature of precipitation in southern Nevada, August 1983 August 1986, U.S. Geological Survey open-file report, 87-463, 1987.

Mix, A. C., and W. F. Ruddiman, Structure and timing of the last deglaciatıon: Oxygen-Isotope evidence, Quarterly Science Review, v. 4, p. 59-108, 1985.

NOAA, Daily Weather Maps, Weekly Series, U.S. Dept. Commerce, Asheville, N.C., 1983-1986a.

NOAA, Climatological Data, California and Nevada, U.S. Dept. Commerce, Asheville, N.C., 1983-1986b.

NOAA, Hourly Precipitation Data, California and Nevada, U.S. Dept. Commerce, Asheville, N.C., 1983-1986c.

NOAA, Storm Data, U.S. Dept. Commerce, Asheville, N.C., p. 25-28, 1983-1986d.

NOAA, Weekly Weather and Crop Bulletin, U.S. Dept. Commerce, Asheville N.C., p. 70-73, 1983-1986e.

Pyke, C. B., Some meteorological aspects of the seasonal distribution of precipitation in the Western United States and Baja California., University of California Water Resources Center Contribution No. 139, 1972.

Riehl, H., Alaka, M. A., Jordan, C. L., and Renard, R. J., The jet stream, Meteorology Monograph, v. 2, p. 23-47, 1954.

Rind, D., Components of the ice age circulation, Journal of Geophysical Research, v. 92, p. 4241-4281, 1987.

Sabbagh, M. E. and Bryson, R. A., Aspects of the precipitation climatology of Canada investigated by the method of harmonic analysis, Annals Association Amencan Geography, v. 52, p. 426-440, 1962.

Simpson, E. S., Thorud, D. B., and Friedman, I., Distinguishing seasonal recharge to groundwater by deuterium analysis in southern Arizona, Proceedings Reeding Symposium, International Association Scientific Hydrology, p. 113-121, 1972.

Smith, G. I., Late Quaternary geologic and climatic history of Searles Lake, southeastern California, in Means of Correlation of Quaternary Successions: Proceedings of the Seventh Congress of the International Association for Quaternary Researach, v. 8, edited by R B. Morrison and H. E. Wright, Jr., Salt Lake City, Utah, University of Utah Press, p. 293-310, 1968.

Sonntag, C. E., Klitzock, E. P., Lohert, K. O., Junghaus, O., Thorweiche, K., Weistoroffer A., and Swaiten, F. M., Paleoclimatic information from deuterium and oxygen-18 in ${ }^{14} \mathrm{C}$-dated north Saharan groundwaters: Ground water formation in the past, Isotope Hydrology, I.A.E.A., Vienna, Austria, p. 569-581, 1979.

Spaulding, G. F., Leopold, E. B., and Van Devender, T. R., Late Wisconsin paleoecology of the American Southwest, in The Late Pleistocene of the United States, edited by S. C. Porter, University of Minnesota Press, p. $259-293,1983$. 
Van der Straaten, C. M., and Mook, W. G., Stable 1sotopic composition of precipitation and climatic variability, in Paleoclimates and Paleowaters: A Collection of Environmental Isotope Studies, Proceedings Symposium Vienna, I.A.E.A., Vienna, p. 53-64, 1980.

White, A. F., and Chuma, N. J., Carbon and sotopic mass balance models of Oasis Valley-Fortymile Canyon groundwater basin, Southern Nevada, Water Resources Research, v. 23, p. 571-582, 1987.
Winograd, I. J. and Riggs, A. C., Recharge to the Spring Mountains Nevada: isotopic evidence, Geological Society of America Abstract with Programs, v. 16, p. 698, 1984.

Winograd, I. J., and Thordarson, W., Hydrogeologic and hydrochemical framework, south central Great Basın, Nevada, California with special reference to the Nevada Test Site, U.S. Geological Survey Professional Paper, 712C, 126 p., 1975. 